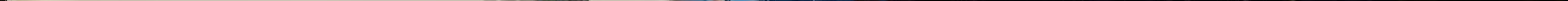


Cover: An NBS electronics technician examines the antenna used in experimental time broadcasts. These broadcasts are part of a program begun at NBS over 50 years ago to broadcast standard frequencies. Such services have expanded so that they are currently making major contributions to the Nation's space and defense programs, to world-wide transportation and communications, and to a multitude of industrial operations, as well as providing convenient time services to thousands of listeners. Photo by Kent T. Higgins. 


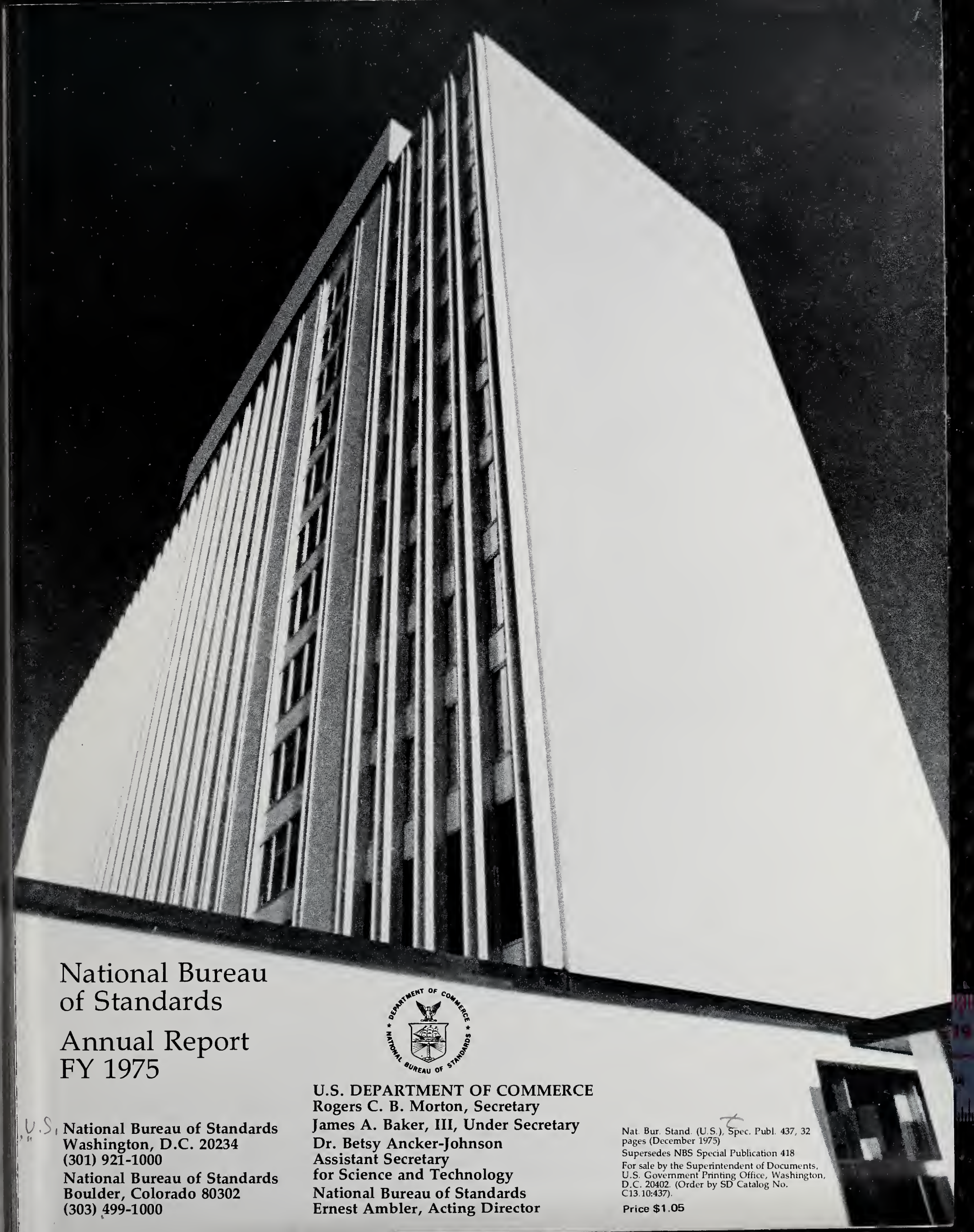




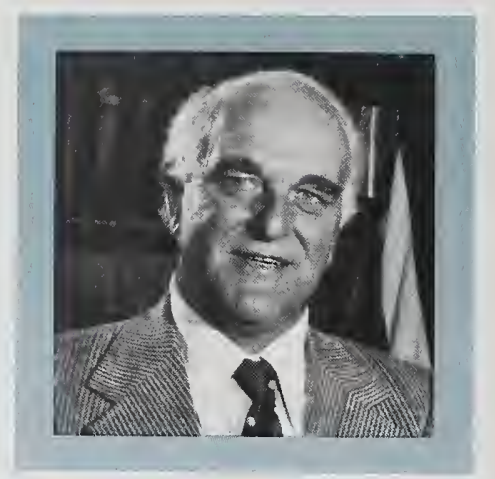

Far right. A breakthrough in the separation of light isotopes using laser chemistry was achieved by NBS scientists in FY75. With this new method "significant quantities" of isotopically enriched boronand chlorine-containing molecules are produced. Such light isotopes are used as tracer elements in medical, environmental, and agricultural research.

\section{A Word to the Reader}

resolving problems of immediate practical importance. Energy conservation ... computer utilization and related issues of privacy ... fire prevention .... environmental protection ... these are a few of the areas where Bureau physicists, chemists, engineers, computer scientists, and other specialists are concentrating their efforts to benefit our economy and society.

This report is being issued on the eve of the Nation's Bicentennial and the Bureau's 75th Anniversary. It seems, therefore, an appropriate time for reflection and rededication-reflection on accomplishments in the past and rededication to meet the challenges and opportunities of the future.
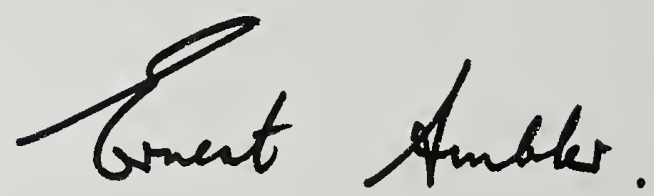

Ernest Ambler Acting Director 

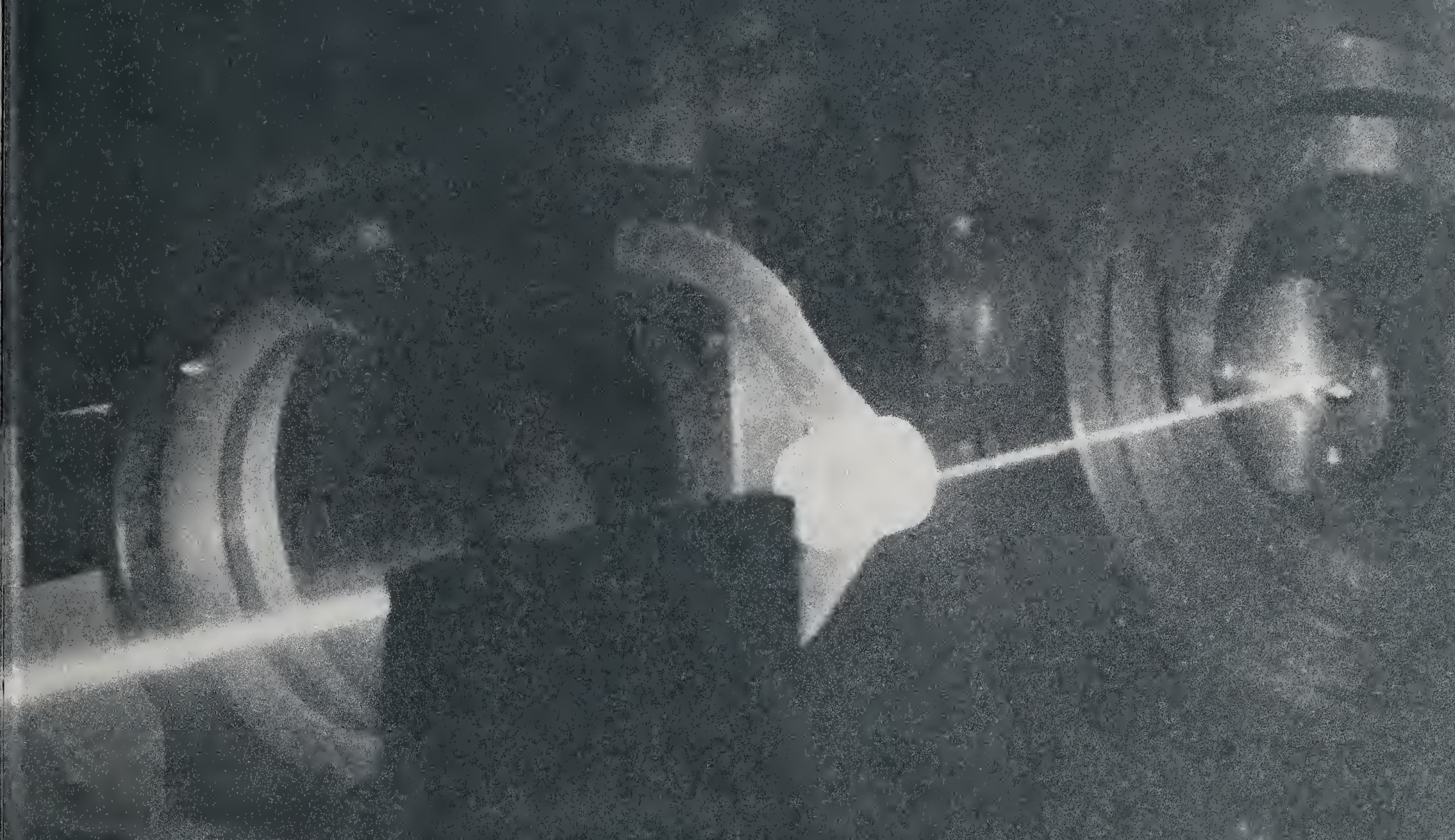


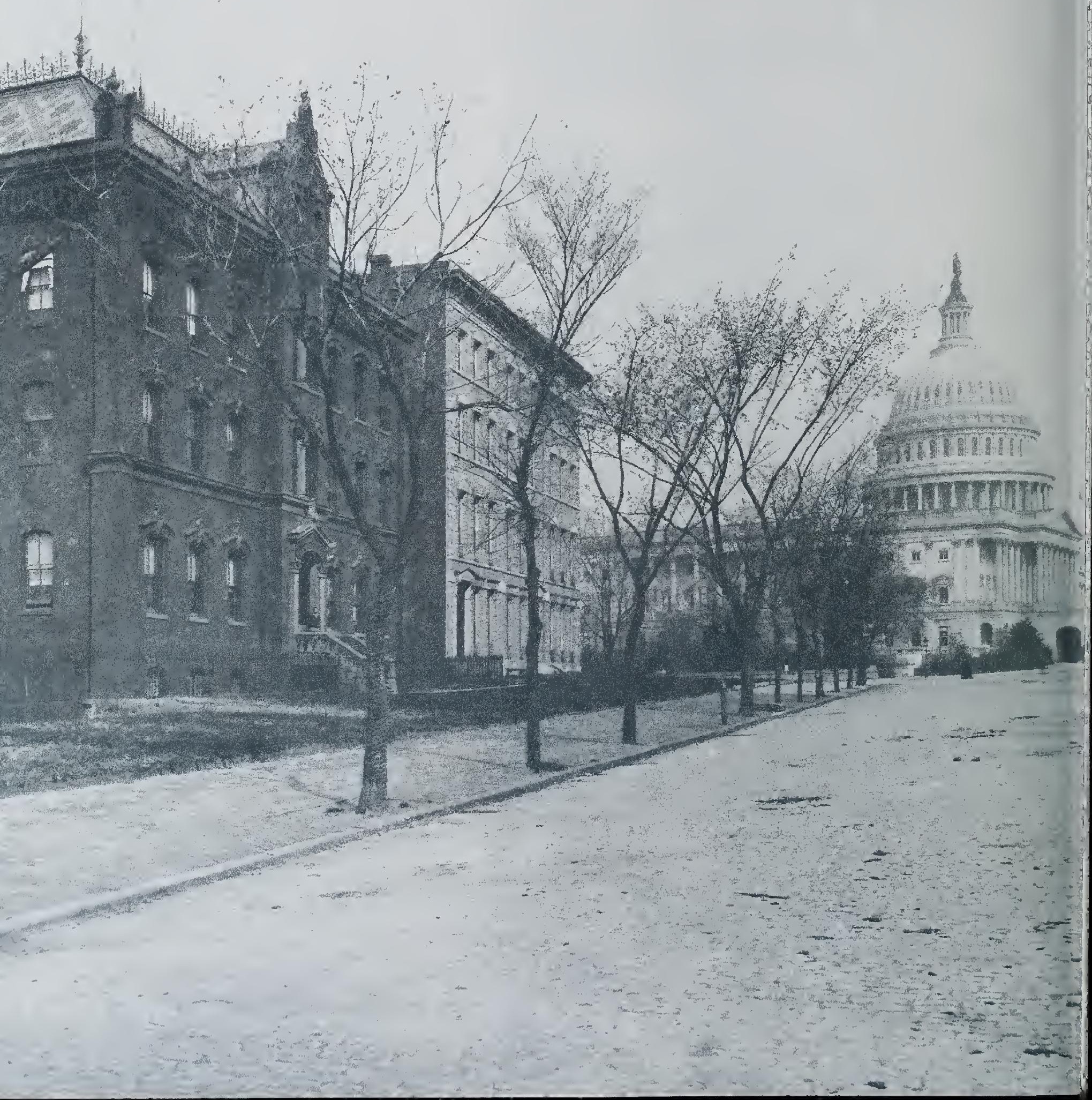




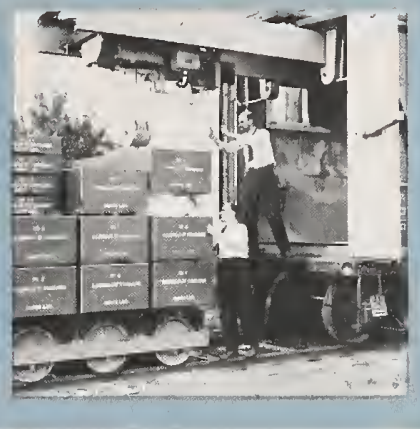

\section{THROUGHOUT the years, the National} Bureau of Standards has helped provide the scientific and technical base for the advancement of the Nation's industry and commerce. The Act of March 3 1901, as amended, which established the National Bureau of Standards, specified that NBS is responsible for:

$\square$ The custody,

maintenance, and

development of the national standards of measurement, and the provision of means and methods for making measurements consistent with those standards, including the comparison of standards used in scientific investigations, engineering, manufacturing, commerce, and educational institutions with the standards adopted or recognized by the government.

$\square$ The determination of physical constants and properties of materials when such data are of great importance to scientific or manufacturing interests and are not to be obtained of sufficient accuracy

elsewhere.

$\square$ The development of methods for testing materials, mechanisms and structures, and the testing of materials, supplies, and equipment including items purchased for use of government departments and independent establishments.
Cooperation with other government agencies and with the private organizations in the establishment of standard practices incorporated in codes and specifications. $\square$ Advisory services to government agencies on scientific and technical problems.

Invention and development of devices to serve special needs of the government.

Additional legislation has significantly expanded the Bureau's primary mission of enhancing measurement science. Accordingly, NBS is deeply involved in such activities as fire safety research and development and improving governmentwide use of computer and automation technologies.

The history of NBS has been marked by numerous contributions in the fields of science and technology. NBS has been instrumental in the development of:

$\square$ The first neon tube, heralding the start of a new industry in the 1930's-1904. $\square$ The radio direction finder, forerunner of modern aviation instrument landing systems-1915.

$\square$ The proving ring for calibrating testing machines whose deflection under load is accurate to within a few hundredths of a millimeter1926.

$\square$ A new radiosonde system, one of the most important contributions to the study of weather patterns-1936.
The radio proximity fuze, an early bomb device with built-in intelligence and a major contribution to the war effort-1941.

The original waterpropelled turbine dental drill, forerunner of the highspeed air drills that are standard equipment in all modern dental offices-1951. The first production line book in which the tables were composed by a photocomposition machine controlled by the output of a digital computer-1962. The highest direct frequency measurement ever made, linking for the first time the international standards for length and time-1972.

The following pages contain a few examples of the activities and accomplishments of the National Bureau of Standards during the fiscal year which ended June 30 , 1975. They reflect the broad range of interests and concerns which characterize NBS as it continues to serve a growing Nation.
Left. The Coast and Geodetic Survey building, home of the Office of Weights and Measures as it appeared in 1900. The Butler building into which the new Bureau of Standards moved is believed to be the structure next door.

Top. Shown is the first NBS railway scale test car for the standardization of railroad track and master scales.

Bottom. In 1950, the Bureau helped devise a method to air seal the Declaration of Independence in a frame to protect this vital document from the combined destructive action of light, atmospheric gases, and changes in temperature and humidity.

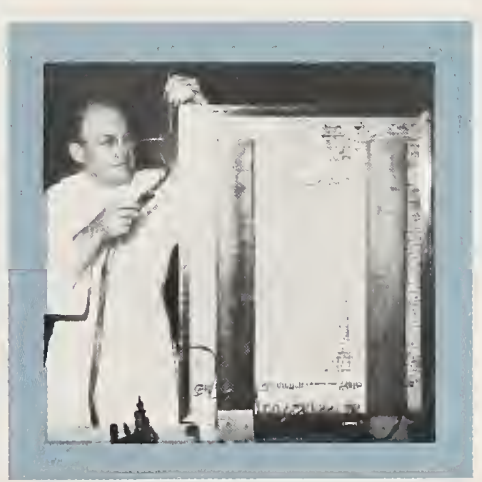


Top. The Bureau's improved Synchrotron Ultraviolet Radiation Facility is inspected by Joseph McMenamin, physicist. The synchrotron is used for studies in atomic, molecular,

biomolecular, and solid state physics; chemistry;

engineering; and medicine.

Bottom left. Leslie

Guildner, NBS physical

chemist, is shown here with the cell that was used to measure the vapor pressure of water at its triple point. The accuracy of the measurement was improved a 100-fold.

Bottom right.

Temperature measurements, sensitive to $0.01^{\circ} \mathrm{C}$, are possible in biological material heated by radio frequencies with this new probe designed by NBS physicist Ronald Bowman.

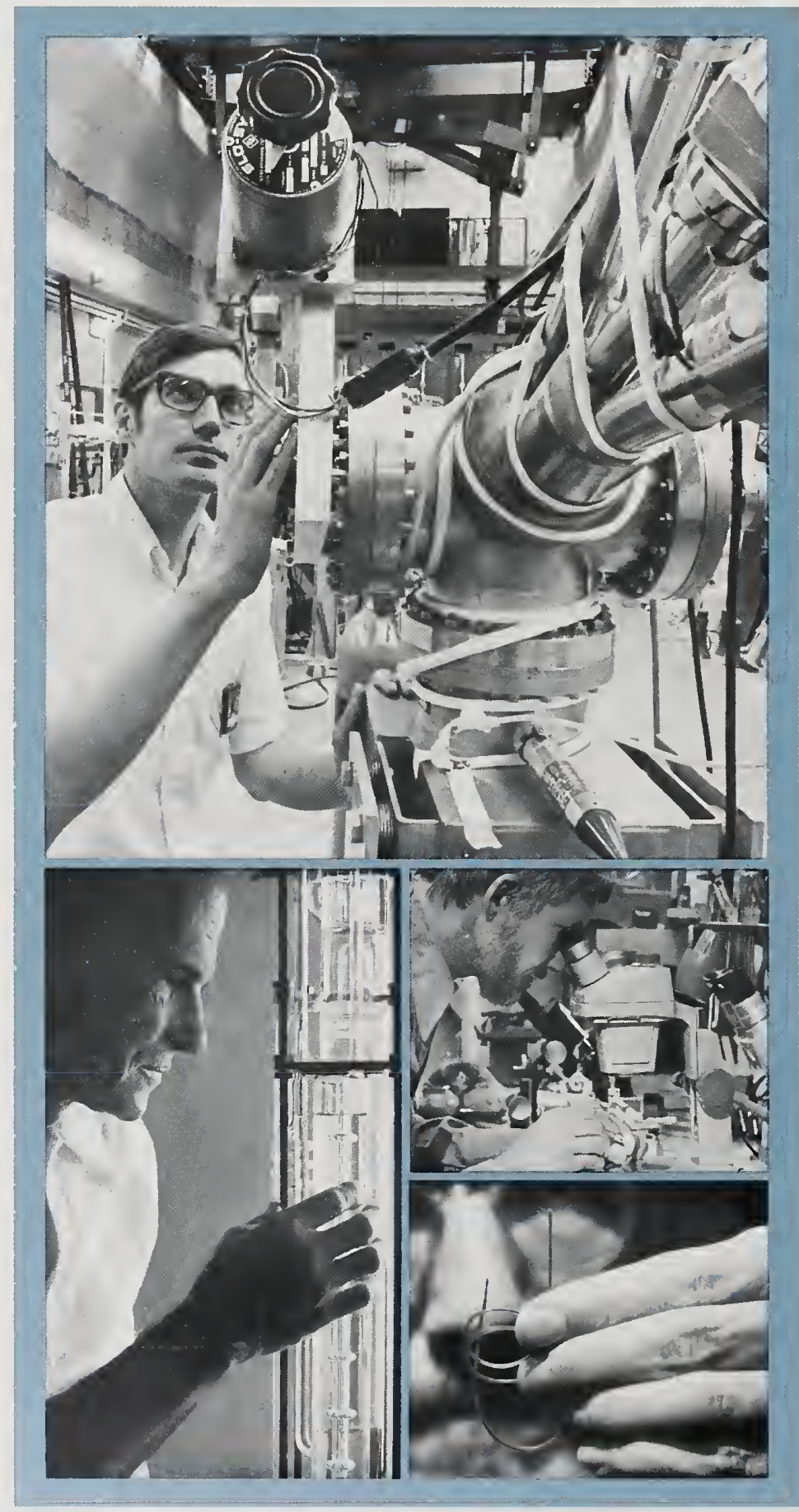


A LL science depends on answers to basic questions. Without the answers there would be no measurement standards and no data for problem-solving. During fiscal 1975, scientists at NBS increased the body of scientific knowledge with many measurement accomplishments.

One of the year's most significant achievements was the use of a laser to "enrich" or concentrate boron and chlorine isotopes. In the experiments, Bureau scientists used laser radiation to selectively excite molecules containing a boron or chlorine isotope. The resulting chemical reactions yielded milligram quantities of enriched isotopic materials-amounts at least 10 times greater than any previously reported. The consequences are important, since improved techniques for obtaining significant quantities of isotopes of boron, chlorine, and other chemical elements are needed for environmental, agricultural, and medical research.

Bureau scientists also made a 100 -fold improvement in the accuracy of measuring the triple-point of water-the transition point where solid, liquid, and vapor are in equilibrium. The benchmark measurement is expected to have wide impact. It can serve as the underpinning for pressure-volumetemperature and thermodynamic tables that are applied in steam power technology, humidity measurements, and meteorology.
Some NBS projects during the year investigated outer space. Bureau researchers helped prove the presence of organic molecules in interstellar space by detecting and calculating their radiation wavelengths. One of these molecules-dimethyl etheris the largest, most complex interstellar molecule ever detected. In a related discovery, NBS scientists were among the first to detect interstellar ethanol, or grain alcohol. Besides adding to our understanding of astronomy and basic chemical reactions, these findings may help answer questions about the origin of life in other parts of the universe.

\section{Other Bureau}

achievements were directed toward improving American health care. Diathermy, which uses heat generated by electricity, is a common medical treatment. A newly developed temperature probe, for example, permits accurate measurement of diathermic heating of biological materials for the first time. The new probe reduces the error of previous methods to around 1/100th of a degree Celsius when the surrounding material is being heated at about a degree Celsius per minute. This measurement breakthrough will help control potentially hazardous electromagnetic conditions during treatment of the patient.

In a separate project, NBS and the National Institutes of Health (NIH) began work to determine the structure of biological molecules. The goal is to provide detailed information on hydrogen bonds and water molecules. Such biological systems play an important role in biochemical and life processes. The Bureau and NIH also began a 3-year effort to develop and clinically evaluate ultrasonic techniques for medical diagnosis.

NBS research even played a unique role in the life of fish. In a joint program with the Washington State Department of Fisheries, the Bureau developed a largescale mathematical model for efficient management of salmon hatcheries. The model contributed significantly towards increasing the hatchery systems' productivity, according to state officials.

Facilities for basic research were upgraded during the year. An improved Synchrotron Ultraviolet Radiation Facility, SURF II, increased the amount of ultraviolet radiation available for NBS experiments by as much as 100,000 times. Extreme ultraviolet radiation is important in experiments on controlled nuclear fusion energy sources, in the fabrication of miniaturized electronic circuits, and in other high-technology research.

A new time-of-flight facility completed in FY75 increased the capabilities of the Bureau's linear accelerator. Researchers can now measure to a greater accuracy neutron crosssections of different nuclei, including uranium-235. Data generated by the facility are needed to design and economically operate nuclear reactors.

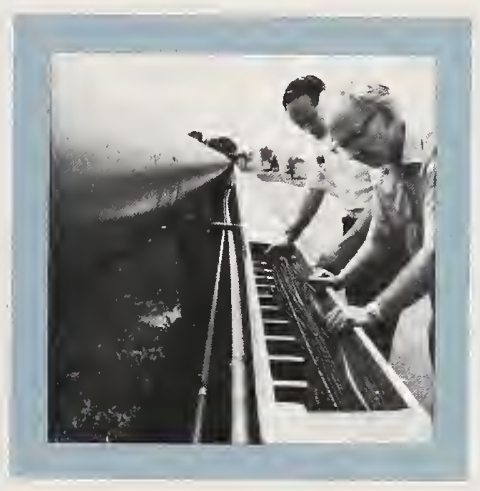

NBS research physicists Roald Schrack and Allan Carlson inspect the time-offlight facility, which is a major addition to the Bureau's electron linear accelerator experimental complex. 


\section{Sharing \\ Measurement Techniques}

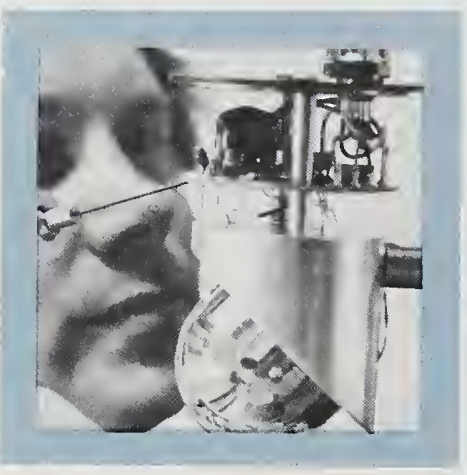

This radiometer designed at NBS Boulder automatically measures optical powers spanning wavelengths from ultraviolet to far infrared. Clark Hamilton, an electrical engineer, designed the detector mechanism.

Right. Interlaboratory standards in microwave technology are now calibrated with a modified automatic network analyzer at a considerable cost reduction compared to previous manual calibrations.
$\mathrm{T}$ $\mathrm{O}$ be useful, measurements must not only be accurate and precise, but they must also be available to those who move measurement techniques from the laboratory to the marketplace and problemsolving level. NBS'

measurement capabilities are disseminated to its customers in a number of ways.

Each state is responsible for maintaining uniform weights and measurements within its boundaries. Last year, NBS helped the states of Massachusetts, Montana, and Louisiana meet their responsibility by giving them new sets of model weights and measures. By the end of the fiscal year, 44 states and the District of Columbia had received new standards in the NBS program which began in 1965 to update measurement capability throughout the country.
Through its calibration services, the Bureau is an impartial measurement referee. The emphasis is on calibrations that require direct comparison to accurately maintained national standards. In this case, customers deliver their measurement instruments to the Bureau where they are calibrated against national standards.

Fees are charged to cover the costs of this nonprofit service. When a test method is simplified, calibration costs are proportionately reduced. In FY75, for example, NBS automated some calibration procedures used in microwave technology and reduced the cost per frequency point from $\$ 400$ to $\$ 35$. Similarly, the Bureau showed a state metrologist how only $\$ 500$ worth of offthe-shelf equipment, coupled with radio signals from NBS radio station WWV, could be used in calibrating the tuning forks needed to check the accuracy of police radar equipment.

This allowed the customer a significant savings as previously the forks were sent to NBS for calibration.

The Bureau's

Measurement Assurance Program (MAP), a supplement to regular calibration services, allows other laboratories to check the performance of their measurement systems. NBS ships a newly calibrated transport standard to the customer's laboratory, where it is calibrated by that laboratory's personnel using their normal method. Results obtained by the participating laboratory are sent to NBS where they are processed and compared with those obtained by NBS before and after shipment. By this technique, the customer's measurement system and capability are evaluated and his primary standard is not subjected to the hazards of travel.

Standard Reference Materials (SRM's) are an integral part of NBS programs aimed at sharing measurement expertise with the scientific and engineering community, commerce, and the public. Manufacturers of secondary standards use these primary standards to calibrate their own measurement systems. With the addition of 40 new SRM's in FY75, the number of Standard Reference Materials available rose to over 900. These "for sale" items range from standards for clinical thermometers to standards for measuring the 


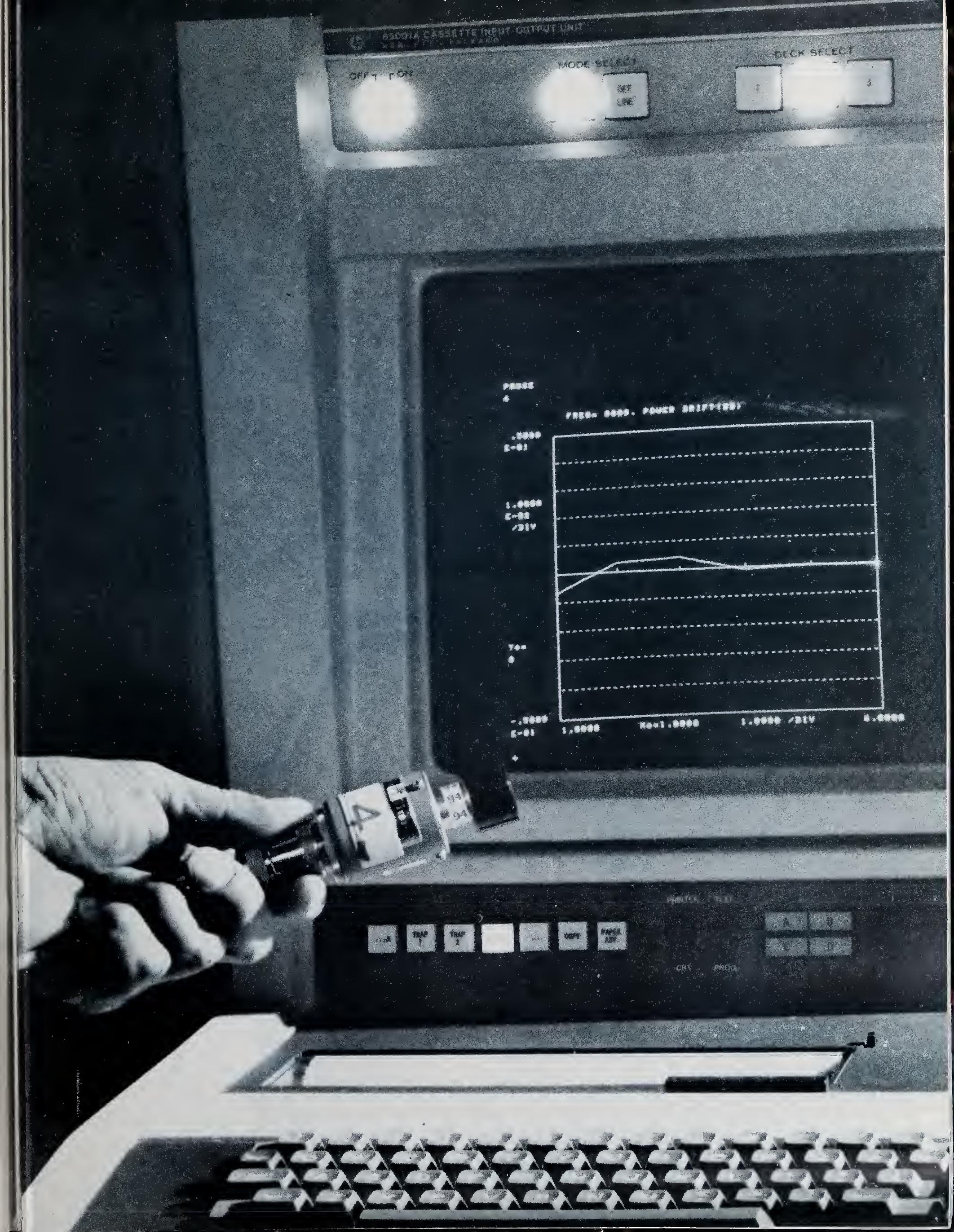

그른 


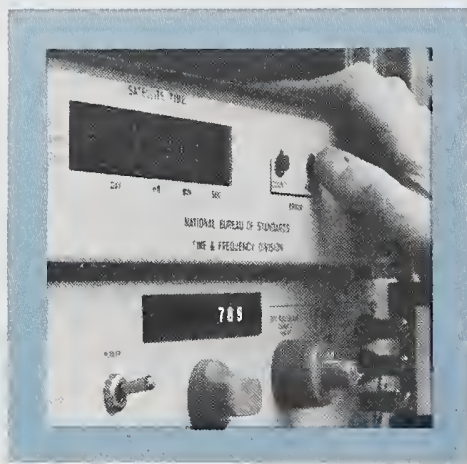

Top. Via a satellite, NBS experimentally broadcasts reliable day, hour, minute, and second time signals spanning 40 percent of the world.

Bottom. Electronics technician Alvin Clements checks the surface of the antenna currently under evaluation by NBS for reception of its experimental time signals.

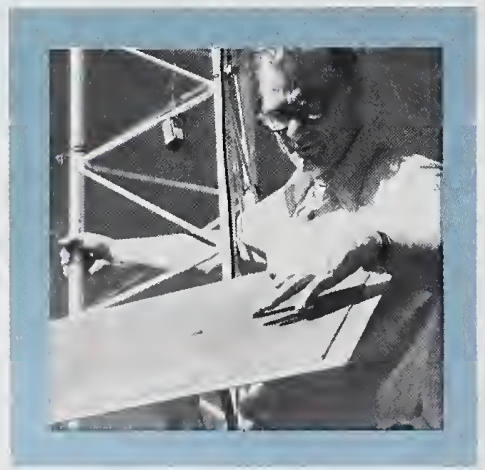

quantity of lead in reference fuel. In FY75 over 30,000 SRM's were sold domestically and overseas. Time-of-day radio announcements are among the Bureau's most widely used services. Using conventional shortwave receivers, anyone can hear continuous time

announcements-accurate to within 1 millisecond or one one-thousandth of a second-from NBS radio station WWV in Ft. Collins, Colorado, or WWVH in Hawaii on 2.5 , 5, 10, 15, and 20 megahertz (MHz). WWV also broadcasts on $25 \mathrm{MHz}$. Recorded time and frequency information is available to the public from WWV by calling (303) 499-7111 and from WWVH by calling (808) 335-4363. More than 18,000 people per week call WWV and WWVH for their recordings, which are accurate to within 30 milliseconds.

In addition to sharing proven calibrations, NBS works at developing new

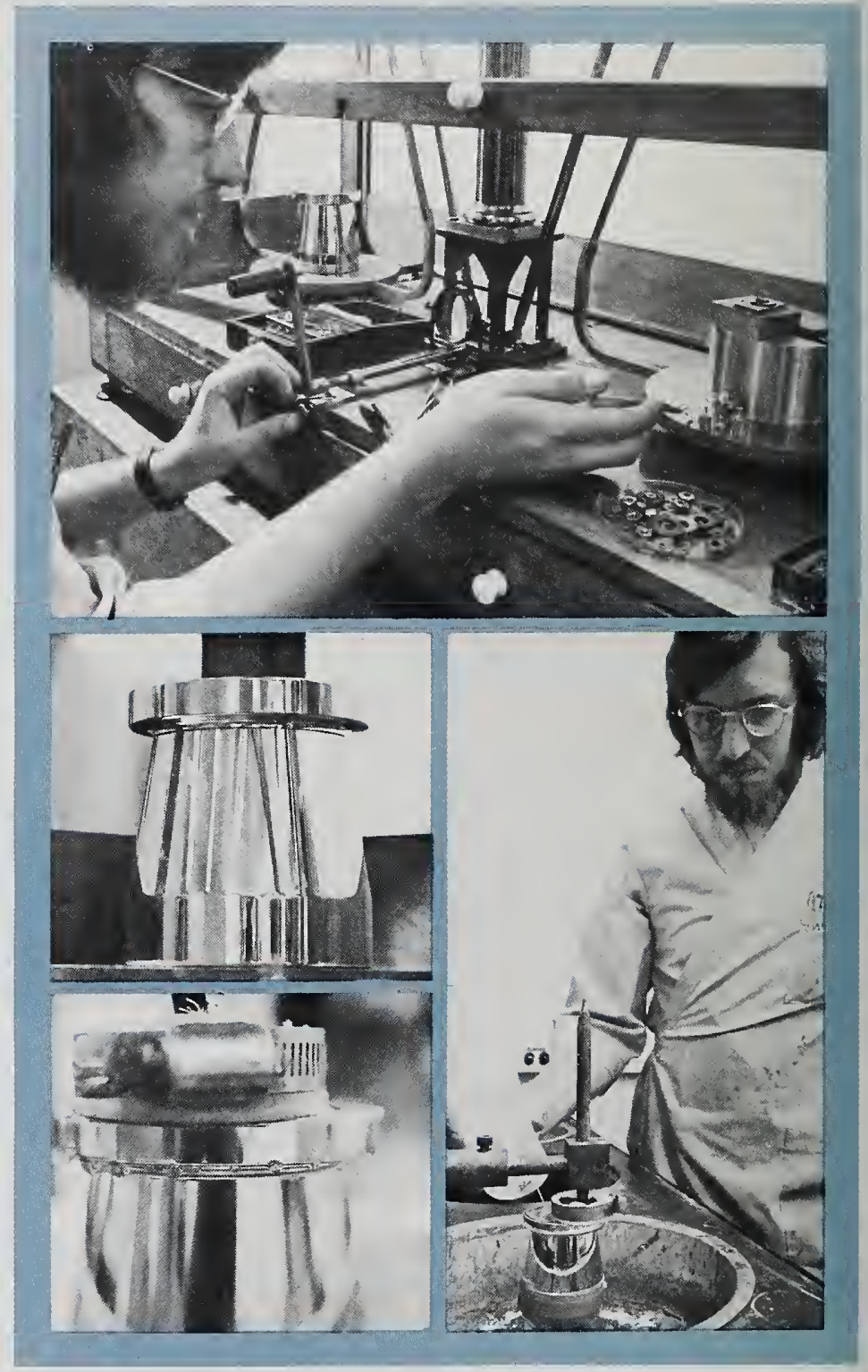

Above. William Dahlberg, apprentice machinist, is shown here polishing and calibrating weights distributed to the states by NBS to help them maintain uniform weights and measurements.
Right. This electrically calibrated pyroelectric radiometer designed by NBS sensitivity and convenience with the inherent accuracy of internal electrical calibration. physicist Jon Geist combines 
and more accurate measurement techniques. In FY75, the Bureau of Radiological Health (BRH) and NBS carried out a nationwide pilot survey of cobalt- 60 sources used in radiation therapy. This work will assure that the amount of radiation prescribed for the patient and the dose actually received are the same.

During FY75, the Bureau continued to develop measurement assurance programs for the 1968 Radiation Control for Health and Safety Act. As part of these programs, researchers designed a completely selfcontained system for determining laser power. Using special electronic techniques, an instrument was developed which converts optical measurements directly into electrical units. The new system is considerably faster and more sensitive than other instruments.

Bureau researchers also developed techniques which use signals from television networks to calibrate oscillators that generate radio or audio frequencies. Using less than $\$ 50$ of equipment, users can plug into a color television receiver and calibrate oscillators to an accuracy of one in $10,000,000,000$ in a matter of minutes.

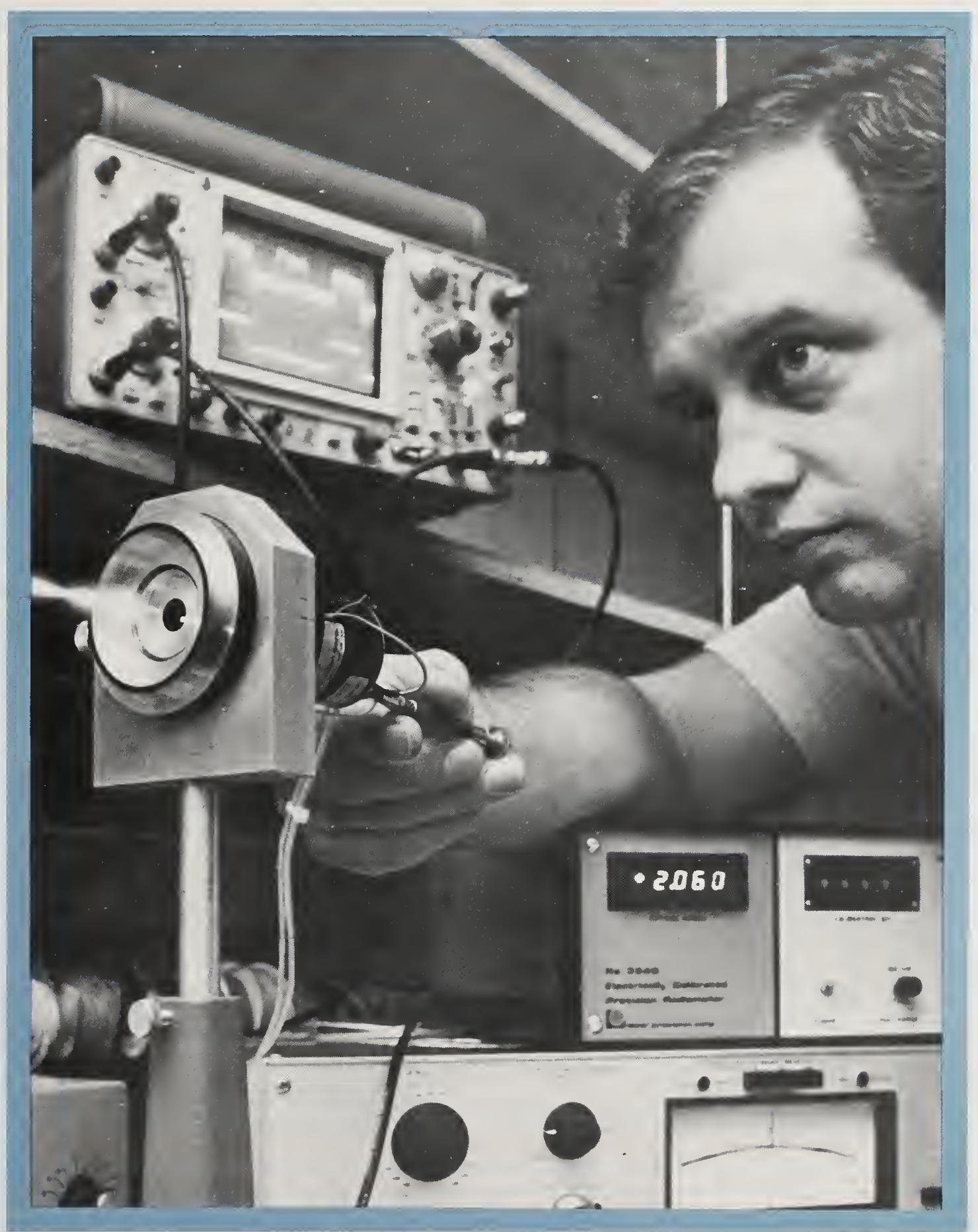




\section{1,21}

$x+2) y_{y} 2$

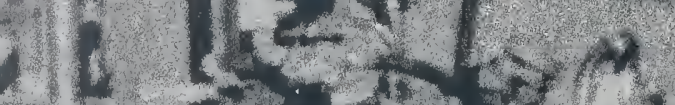
1.

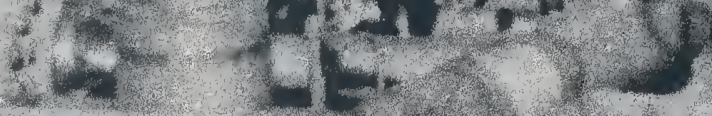

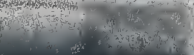

25
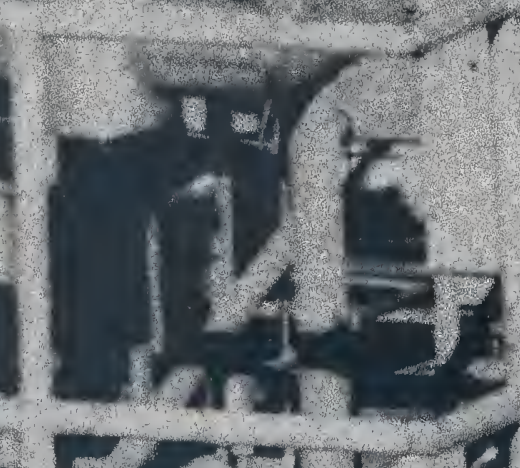

$\frac{2+25}{2+2}$

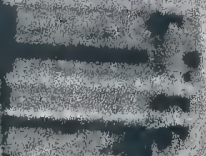

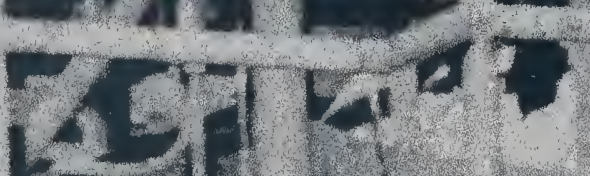

1

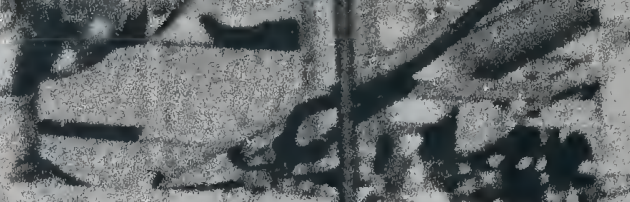

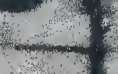

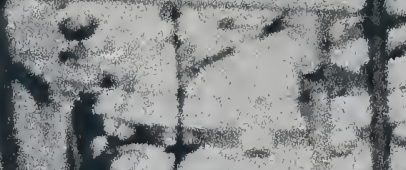

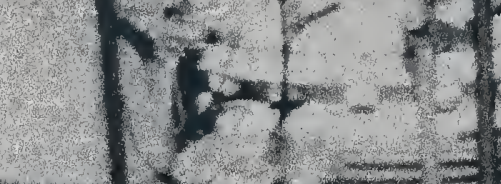

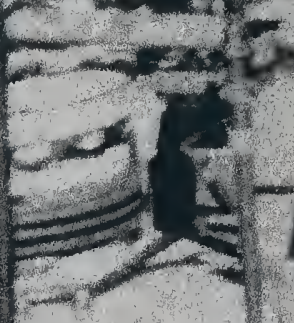

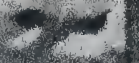

3.t.

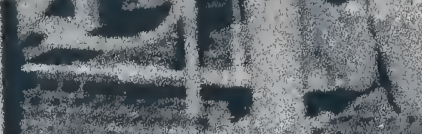

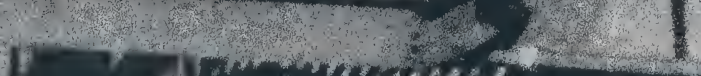

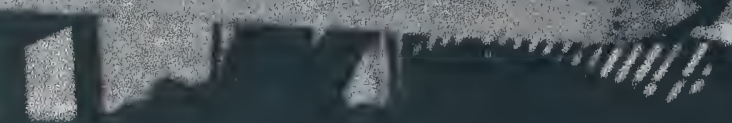

-

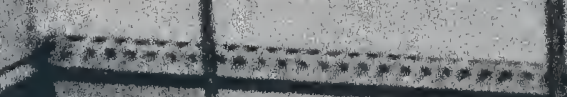

2.

(n)

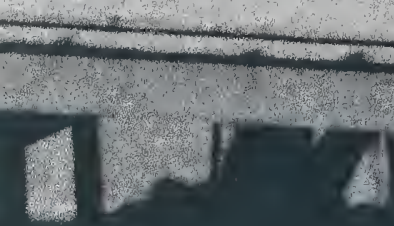

$\cos ^{2}$ (6)

(1)

she

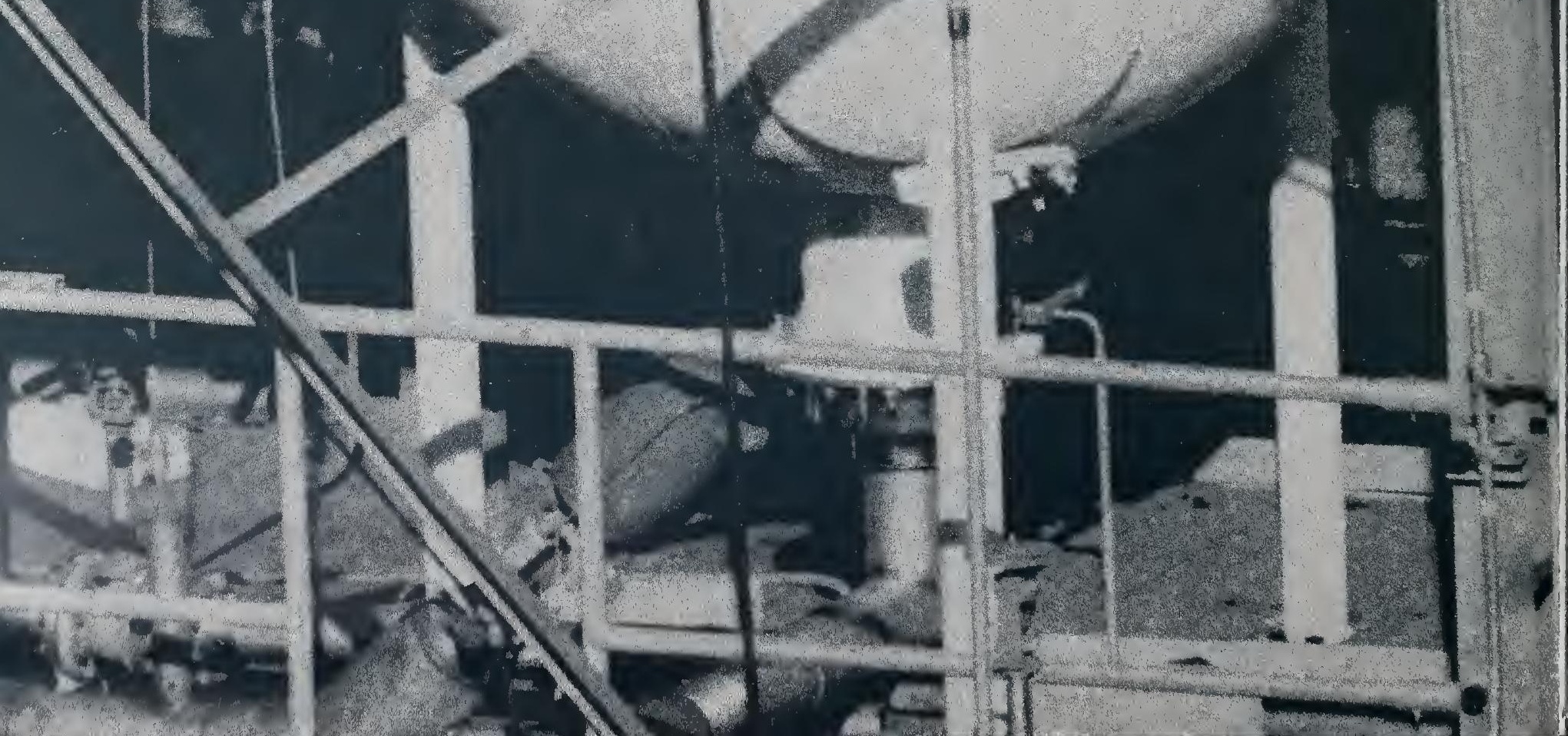

$\operatorname{con}$

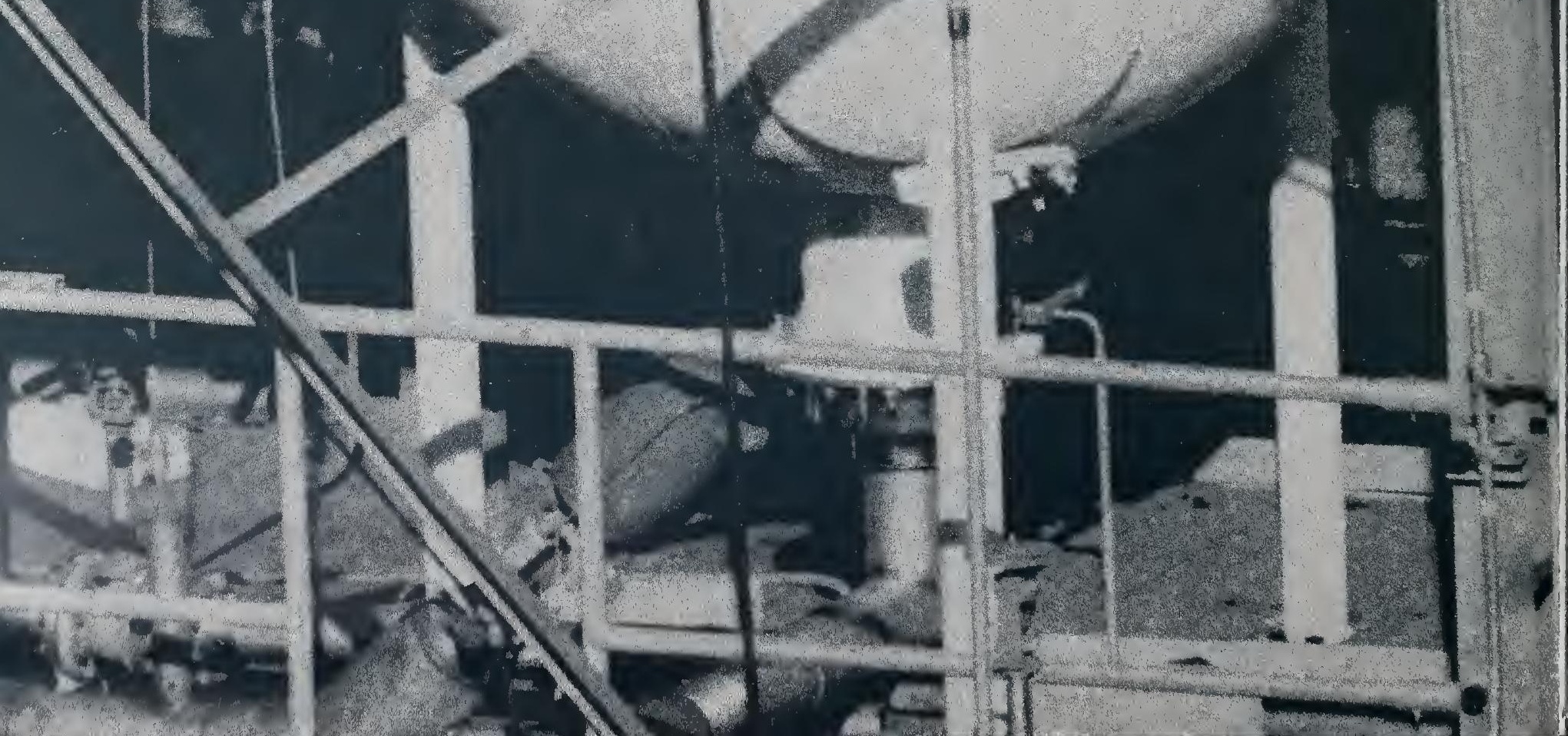

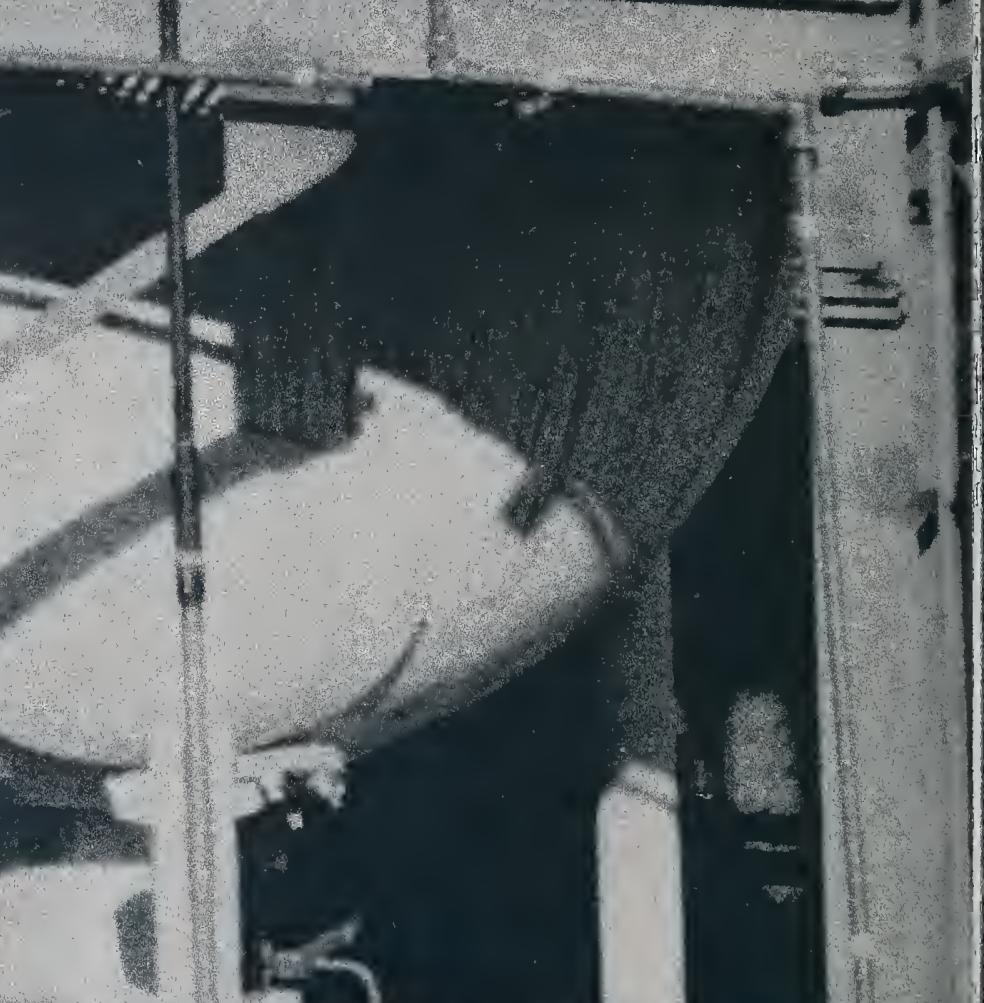

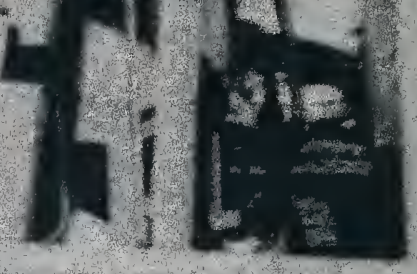

3

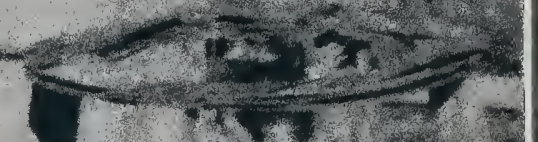
$7,13^{-20}$ $y+15$ 


\section{Exploring Our Energy Options}

Juse UST 2 years ago, there were long lines at gasoline stations. Prices of gasoline, home heating oil, and other petroleum products soared as available supplies dropped drastically. Thus, the need for new energy sources for the future and efficient energy use now became a major national concern. At the Bureau, during FY75, scientists began answering such diverse questions as "How feasible is a solar home?" and "How much money can insulation save on home heating and cooling bills?"

The sun is an enormous potential source of energy. Finding new ways to tap this energy is the goal of the 1974 Solar Heating and Cooling Demonstration Act. Under the Act, the Bureau developed interim performance criteria for solar heating and cooling systems for the Department of Housing and Urban Development.
In a separate project, Bureau scientists developed proposed performance standards for solar collectors and thermal storage unitsthe keys to all solar systems. These proposals were submitted to the American Society of Heating, Refrigerating, and Air Conditioning Engineers for approval as ASHRAE standards. At the same time, testing continued on a solar heating and cooling system in a four-bedroom townhouse on the Bureau grounds. The goal is to develop standards for solar heating and cooling systems in residences.

Bureau experts also worked for the improved measurement of other energy sources. Liquefied natural gas (LNG) is shipped and traded daily in quantities up to 72,000 cubic meters. To give the buyer and seller measurement confidence, NBS scientists studied ways to standardize commercial measurement of LNG.

During the course of this program, Bureau staffers compiled the most accurate and comprehensive data available on the

thermodynamic properties of methane and ethanecomponents of natural gas.

During the year, NBS turned its attention to magnetohydrodynamics or MHD, a way of generating electricity from fossil fuels, especially coal, or from nuclear fuels. Blocking the way to practical application of MHD are problems concerned with the durability of materials that will be used to construct MHD systems. For this reason, NBS scientists are gathering information which will be used in the testing of materials for MHD power plants.

The Bureau also has an active program in coal gasification, a way of converting coal into a gas for energy use. During the year, NBS scientists worked to

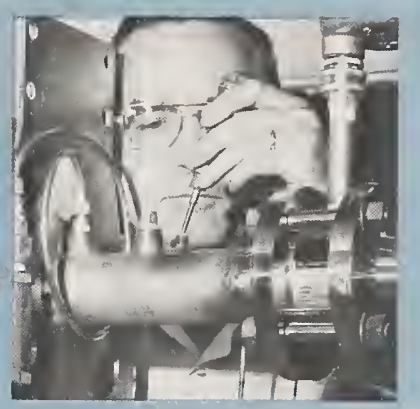

Left. Flow rates and heating values for energy fuels, such as liquefied natural gas, are determined at NBS Boulder at this large-scale outdoor flow facility.

Top. Volumetric flow rates and density and calorimetric measurements are combined to determine the total heating value of liquefied natural gas. Here staff scientist James A. Brennan adjusts test flowmeter.

Bottom. NBS physicist William Hosler loads samples in furnace to measure hightemperature electrical conductivity of materials that are potentially useful in MHD generating systems.

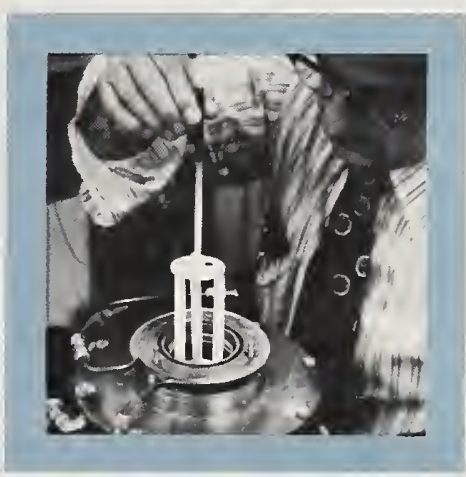




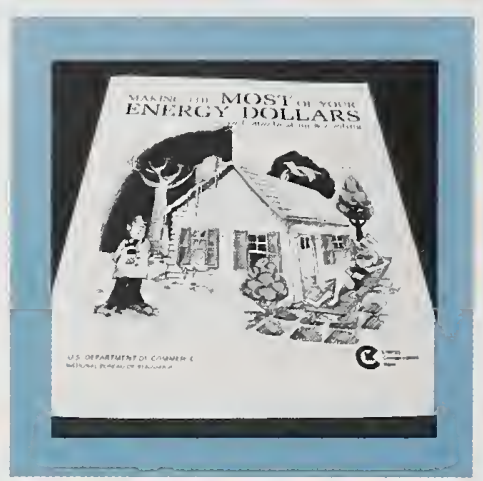

Top. Making the Most of Your Energy Dollars, a new consumer information booklet published by NBS and the Federal Energy Administration, provides guidelines to homeowners in determining the most cost-effective energy improvements for their homes.

Right. Alternative ways of heating and cooling homes are under study by NBS scientists. Here mechanical engineering technician Theodore Ray, Jr., adjusts instrumentation on a heat pump, one such

alternative, that is being tested in one of the Bureau's environmental chambers, which can simulate temperature and humidity patterns from anywhere in the United States. The laboratory study of heat pumps is part of a larger ef fort aimed at developing test methods for heating and cooling equipment and systems to be used in voluntary standards.

Bottom far right. Mechanical engineering technician Donn Ebberts inspects solar collector system mounted on the roof of the NBS experimental townhouse.

Top far right. This solar system, being checked by mechanical engineer James Hill, is under evaluation for its ability to provide heating, cooling, and hot water for the four-bedroom townhouse. develop methods for measuring corrosion and erosion of materials being tested for use in coal gasification plants. To insure that the test methods function in a "real-life" situation, the Bureau is correlating its laboratory results with materials used inside the Coal Gasification Pilot Plant in Bruceton, Pennsylvania.

Until solar energy, MHD, and other new energy sources are in practical use, there will remain an urgent nee $i$ to conserve the energy we have. More efficient energy use is one way of making conservation easier. Accordingly, the Bureau placed major emphasis on energy efficiency and careful consumption. To help accomplish this, an Office of Energy Conservation (OEC) was formed. Advancing the use of energy-efficient technology in buildings, communites, and industry is $\mathrm{OEC}^{\prime}$ s role.

One of the Bureau's most significant energy conservation advances during FY75 involved industry, which uses 43 percent of all energy consumed in the United States. NBS published the Energy Conservation Program Guide for Industry and Commerce, called EPIC. The guide gives practical and specific hints on energy saving for small and medium-sized companies and for corporate giants. EPIC offers more than 200 energy conservation opportunities with actual case histories showing how

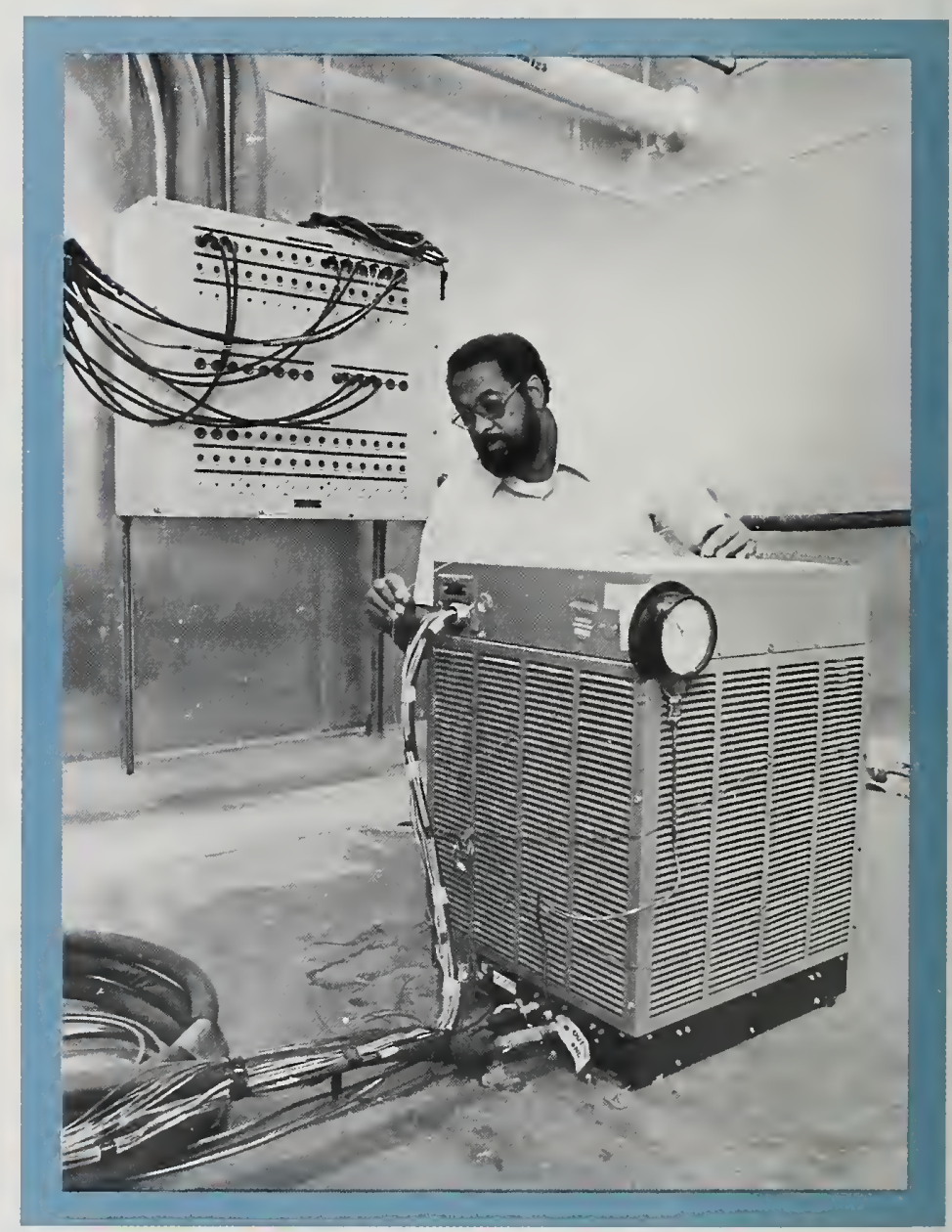

organizations achieved their savings. EPIC is now used as a guide by state energy offices across the country.

Even a complex

laboratory facility with specialized needs can utilize energy more efficiently, as NBS demonstrated during the year. Based on a systems analysis of its energy use, the 
Bureau reduced its energy consumption by about 20 percent in FY75 without disrupting its research and standards programs.

The 40,000,000 owneroccupied homes in the United States are also a major target of Bureau energy conservation efforts. Homeowners can save energy and money by adding insulation to reduce their energy consumption. A new NBS economic analysis shows just how much insulation homeowners should add to get the maximum return on their investment. Based on this technical study, the Bureau published a consumer booklet, Making the Most of Your Energy Dollars-in Home Heating and Cooling. Using this booklet, homeowners can calculate their best combination of energy improvements, based on their climate, energy prices, and investment costs.

The millions of appliances in U.S. homes, as well as the dwellings themselves, should be energy efficient. During the fiscal year, the Bureau continued its appliance labeling program for energy conservation. Manufacturers of 95 percent of all room air conditioners now on the market have agreed to tag their products with an energy label developed at the Bureau. With the help of the label, buyers can compare different models to find the best energy buy. The Bureau also published Energy

Efficiency in Room Air

Conditioners, a pamphlet that describes what consumers need to know to make the best selection.

In his State of the Union message, President Ford announced additional NBS responsibilities in appliance efficiency. To help reduce energy use of new home appliances by 20 percent by 1980, NBS will establish improvement goals for several appliances, specify the test method for gauging improvement, and monitor progress.

The Bureau's

Experimental Technology

Incentives Program (ETIP), which encourages

technological change for economic benefit, demonstrated the dollar savings of energy efficient appliances in FY75. Through an agreement between ETIP and the General Services Administration, the Federal government expects to save $\$ 400,000$ on 27,000 room air conditioners which use 21 percent less energy than comparable models. In a separate agreement with ETIP, the General Services Administration purchased 7,700 gas and electric hot water heaters for military housing. The heaters use up to 11 percent less energy and are expected to save the government $\$ 300,000$ in operating costs.

Consumers, industry, and the scientific community share the need and responsibility for better energy use. The increasing number of energy ideas and inventions reflects this need. To help the Energy Research and Development

Administration evaluate non-nuclear energy ideas, Congress authorized the establishment of a program to evaluate energy-related inventions at NBS during FY75.

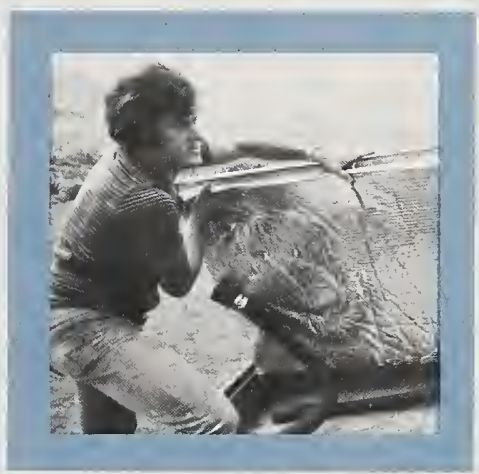

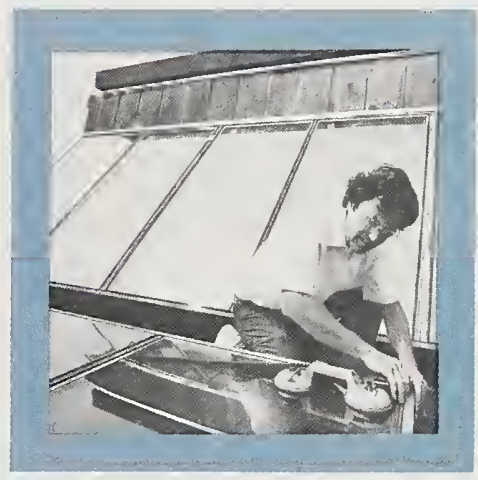




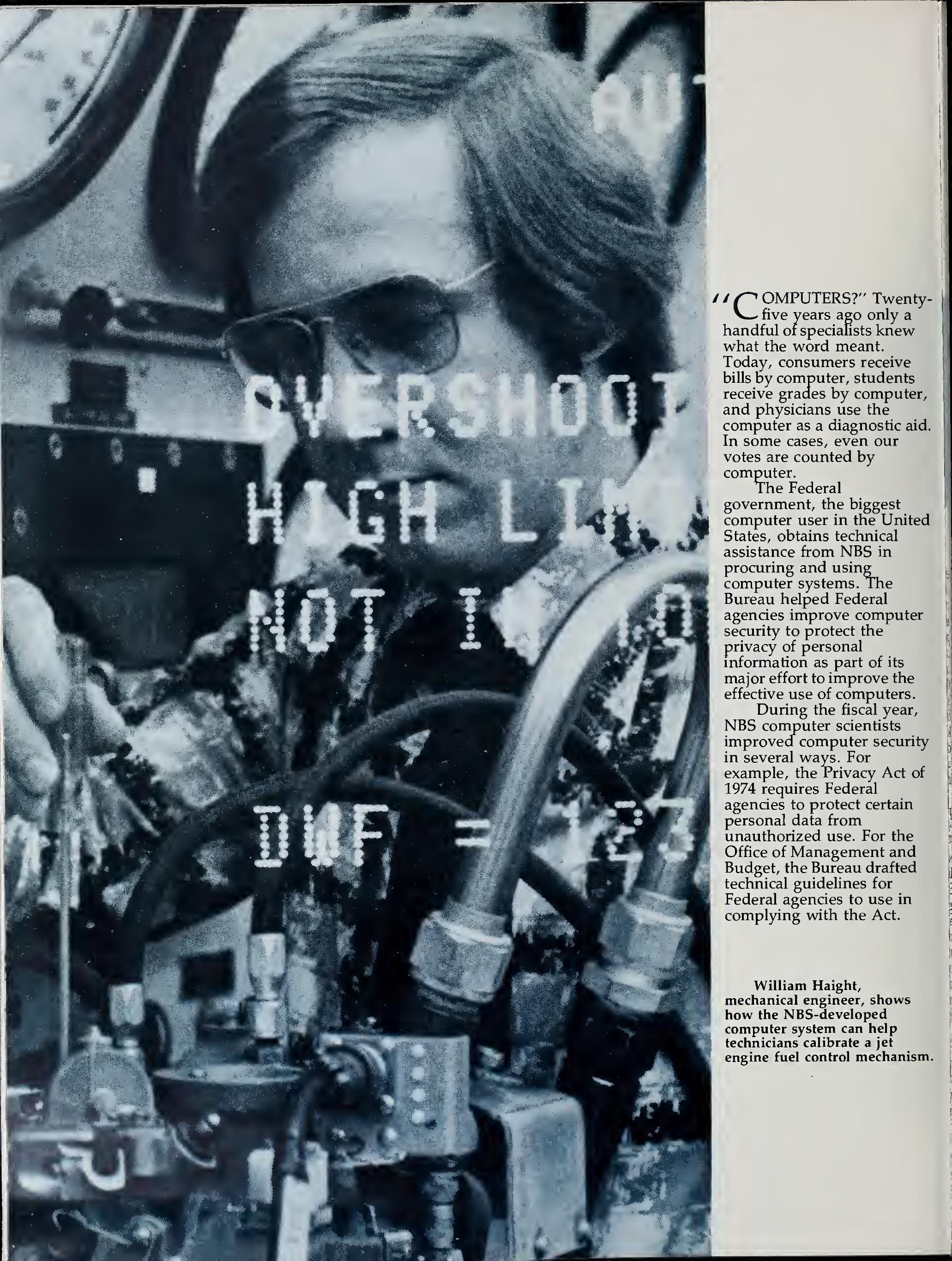




\section{Expanding \\ Computer \\ Utilization}

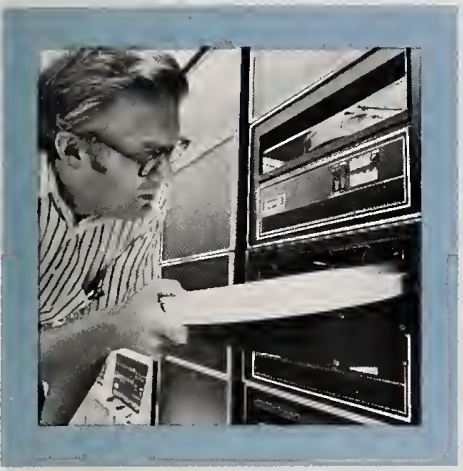

Preliminary to establishing a Federal standard algorithm, NBS published a data encryption algorithm, which can provide high-level security to confidential data. Encryption or coding is achieved through an algorithm which is a set of mathematical steps for scrambling the data and a key. Without the key, the computerized data is unreadable and secure from unauthorized use.

Additionally, the Bureau published Guidelines for Automatic Data Processing Physical Security and Risk Management as a Federal Information Processing Standard (FIPS). The new guidelines will help Federal agencies establish and carry out programs to protect automatic data processing operations against natural disasters, as well as malicious destruction and fraud.

As is the case with all FIPS, other Federal agencies cooperated with the Bureau in this computer standardsmaking process. During the fiscal year, the number of FIPS grew to 40 in the categories of data, software, hardware, quality control, and safety and security.

Computer systems linked by communication facilities (computer

networks) require easy but controlled accessibility. The NBS-developed Network Access Machine (NAM) helps make networks easier to use by translating simple user requests to the detailed system procedures to satisfy them on different networks. The NAM promises to reduce Federal computing costs through more effective use of shared resources.

In some cases, Bureau computer expertise helped in the design of a specific network. The National Weather Service planned a network to collect and disseminate weather data from its 50 weather forecast stations, 200 weather service offices, and several specialized centers. NBS explored the capacity of the network under various operating conditions, analyzed its reliability, and devised alternate plans for coping with a service disruption.

Computer scientists also worked to improve the effective use of computers in the election process. In the 1974 elections, one out of every 10 ballots was counted by a computer. The Bureau recently completed a yearlong study of computerized voting for the Clearinghouse on Election Administration. In a report prepared by NBS and published by the

Clearinghouse, guidelines were proposed for the effective use of computer technology in vote tallying. Local election officials can use the guidelines to assure the accuracy and security of their computerized election results.

Computer components, like other high-technology equipment, require calibration. A new Bureau calibration service for medium density magnetic disk surfaces was launched in FY75. Calibrated reference disks control the quality of production disks and insure that disks are

interchangeable among various computer systems.

The magnetic disk packs are high-speed random access memory devices for the storage and retrieval of digital information in computers.

While most of these accomplishments are aimed primarily at Federal computer use, the spin-offs can influence computers in the private sector. For example, the Bureau developed computer equipment and programs for the Naval Air System

Command's use in automating tests of the fuel control mechanism in jet engines. The automating of the testing of the system will make the Navy's tests faster, easier, and more dependable. Although the NBS system was designed for testing the Navy's jet planes, it can be modified for use in testing other engines as well.
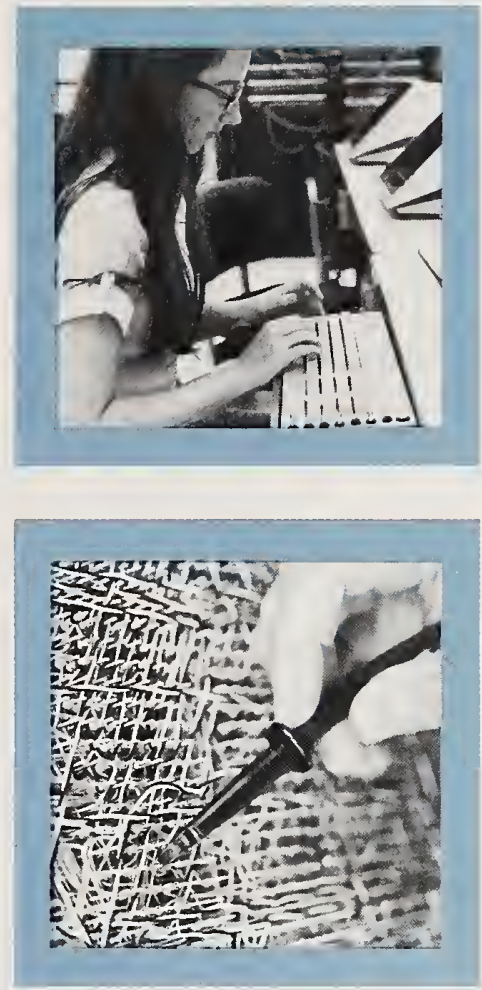

Left. An experimental computer facility supports NBS efforts in preparing Federal standards and guidelines for effective and efficient computer use. Here Don Rippy, electronics engineer, loads a magnetic disk cartridge into one of the minicomputers within the facility.

Above. NBS' networking program is directed toward reducing Federal agencies' costs by preparing Federal networking guidelines. Carol Swearman, mathematics aid, operates a networking terminal.

Bottom. Robert Lach, head of numercially controlled machining, and John Evans, physical scientist, examine parts produced by a numerically controlled (NC) machine tool. The new machine will be used for evaluating performance measures for NC machine tools and in developing computerized manufacturing systems.

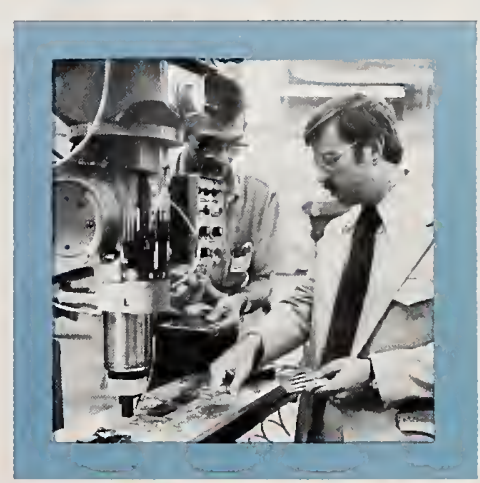




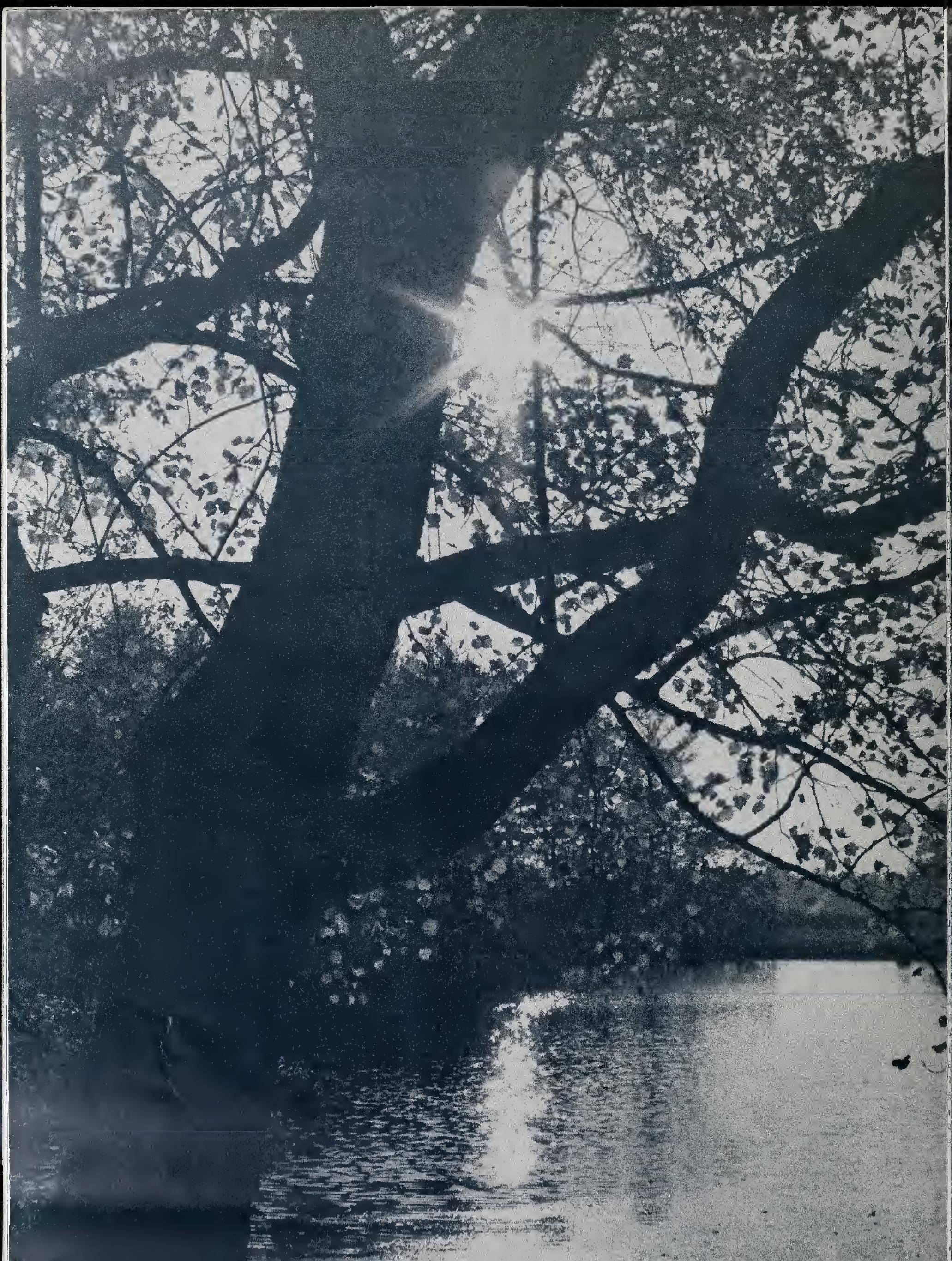




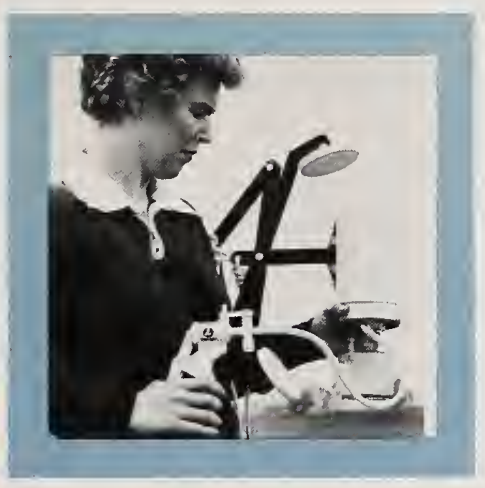

$M$ ILLIONS of cars, thousands of factories, and hundreds of new chemicals: all threaten to decrease the quality of our environment. Accurate measurements, however, can tell us which elements are causing danger and guide us in taking corrective action. In FY75, NBS improved several measurement tools for environmental monitoring and control.

Standard Reference Materials (SRM's) are important tools in this process. They provide a common set of accurate standards which manufacturers and Federal, state, and local agencies can use to compare their measurements. With SRM's, measurements in all parts of the country can be referred to a common base.

Several SRM's

completed during FY75 will

help preserve environmental quality. For example, the Bureau issued two SRM's to measure mercury in water. These SRM's are free of a long-standing problem experienced with prepared mercury solutions, that of the mercury concentration diminishing with time. Bureau scientists solved this problem by stabilizing the solution with gold ions.

Controlling the level of mercury in water is important because some bacteria convert ordinary mercury into deadly methylmercury. When fish eat organisms contaminated by methylmercury, the toxic element enters the human food chain. To guard against contaminated food, we must be able to measure accurately the amount of mercury in water. The stabilized mercury SRM makes this possible.

Other completed air pollution SRM's will help the Environmental Protection Agency (EPA) enforce its clean air regulations. Five separate standards were issued for nitric oxide, which reacts in the air to form nitrogen dioxide, a common pollutant found in the atmosphere and the workplace. The Bureau also made available a new SRM for nitrogen dioxide. Using three other SRM's, fuel producers, regulatory agencies, and consumers have an agreed-upon basis for measuring lead in motor fuel. At the request of the EPA, NBS prepared three SRM's for the detection of trace elements (chemicals present in minute amounts) in fossil fuels.

"Do fluorocarbon aerosol propellants and coolants break down the earth's protective ozone layer?" Answering this crucial environmental question is difficult because details of the breakdown process in the stratosphere are unknown. A recent NBS investigation showed that one and possibly two chlorine atoms are produced during the single fluorocarbon molecule. This information will help explain the role of the chlorine atom in the destruction of the ozone layer.

Although we need ozone in the stratosphere to protect us from ultraviolet radiation, ozone at the earth's ground level is a serious pollutant. Bureau photodecomposition of a

\section{Preserving Environmental Quality}

chemists studied the chemical reaction rates affecting ozone's formation and destruction. In a related project, NBS is carefully evaluating the methods for measuring ozone.

Some environmental concerns strike even closer to home. Vinyl chloride gas, for example, is used in the production of plastics and is an industrial pollutant which may be a cancer-causing agent. During the year,

Bureau scientists developed a sensitive and selective method for detecting vinyl chloride gas. The technique is free from interference from many of the competing molecules (like water and ethylene) in atmospheric samples that "confuse" existing vinyl chloride detectors.

In a nother

environmental achievement, NBS experts developed a technique to measure trace levels of two elementsuranium and tellurium. The technique is sensitive enough to permit measurement of these elements, both potent biotoxins, at their naturally occurring levels, in biological, medical, and environmental materials.

In a related effort, the Bureau began a joint study with the Environmental Protection Agency to determine the feasibility of establishing a National Environmental Specimen Bank. The bank would store environmental samples for analysis of new or nowunmeasurable chemicals with the improved measurement techniques of the future.

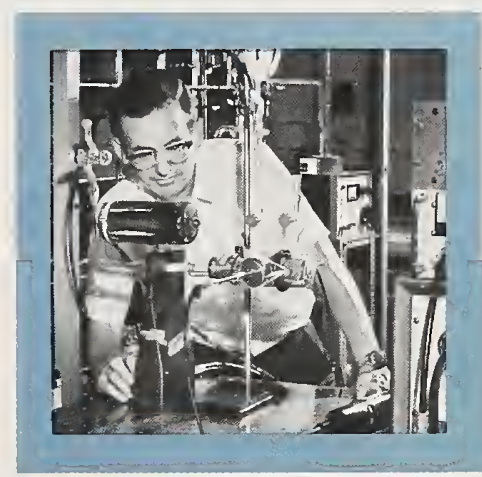

Top left. Chemist Sally Harrison transfers water collected with noncontaminating sampling device she developed. Devices such as this may be used to collect materials for a future National Environmental Specimen Bank.

Above. Richard Rebbert, NBS chemist, examines apparatus used in experiments investigating the light-induced breakdown of fluorocarbons at wavelengths similar to those in the upper atmosphere. 


\section{Promoting Better Materials Use}

$A^{M}$ MERICANS are a consuming people. Each year, every American uses about 18,000 kilograms (a kilogram equals about 2.2 pounds) of natural resources. Since resource supplies are finite, we need to use our materials effectively. NBS made major progress in FY75 in finding better ways to use our dwindling supplies.

Knowing more about materials can save money, as well as resources. American taxpayers spend more than $\$ 70$ million yearly repairing highway bridges damaged largely by de-icing salts. When the Federal Highway Administration asked NBS to test organic coatings for steel reinforcing bars on bridges, 47 different coatings were evaluated. Certain powder epoxies, it was discovered, eliminate corrosion and should at least double the reinforcing bars' lifespan.

Natural hazards can be even more costly. Building failures in the wake of earthquakes, hurricanes, and tornadoes cost $\$ 1$ billion annually. As a first step in reducing these losses, the Bureau published a 964-page study on Natural Hazards Evaluation of Existing Buildings. This pioneer publication tells how to survey typical buildings to determine risks to life and property under natural hazard conditions. In addition, the study presents criteria for community safeconstruction planning.

NBS scientists also investigated overseas natural disasters on-the-spot during
FY75. For example, the Australian government asked the Bureau's help in assessing the damage from a Christmas Day cyclone. The NBS consultant then made recommendations for future design and construction. Knowing the

fundamental properties of materials is crucial to their effective use. NBS and seven industrial firms began a joint project to investigate the thermophysical and thermodynamic properties of ethylene, an unsaturated hydrocarbon found in coal gas. The data are needed for better handling of ethylene in the plant, for equipment design, and for custody transfer of ethylene, which ranks fourth in U.S. chemical production.

With the widespread use of synthetics in medicine and dentistry, proper materials use becomes increasingly important. Synthetic implants, for example, are often used successfully in the human body. However, Bureau studies revealed great variations in implants' surface film which can affect their corrosion rate and surface topography or smoothness. With this information as a working base, NBS researchers will study how manufacturers prepare implant surfaces.

Other Bureau staffers studied the poly(methyl methacrylate) bone cement used in hip joint surgery.

They examined the chemical composition, handling characteristics, and physical properties of the cement. One finding - that bone cement takes about 18 hours to "set" - may serve as a

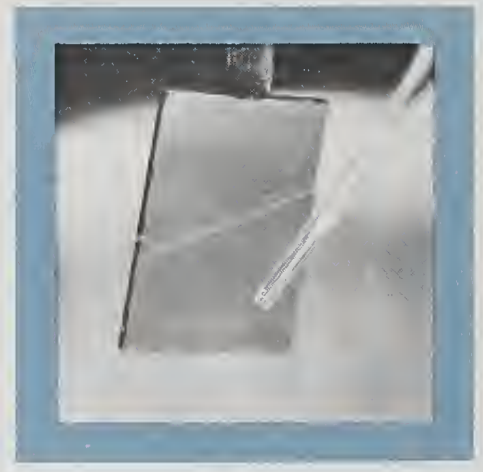

Left and above.

Microstructures and surface films of implant materials are studied by NBS metallurgist Anna Fraker.

Right. An NBS evaluation found that certain epoxy coatings, when applied to steel reinforcing bars in bridges, could double the lifespan of these reinforcing bars.

Bottom. This NBSdeveloped wear device speeds evaluation of dental restorative materials.

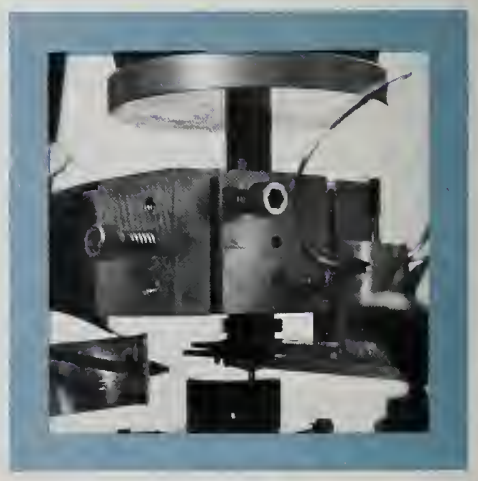



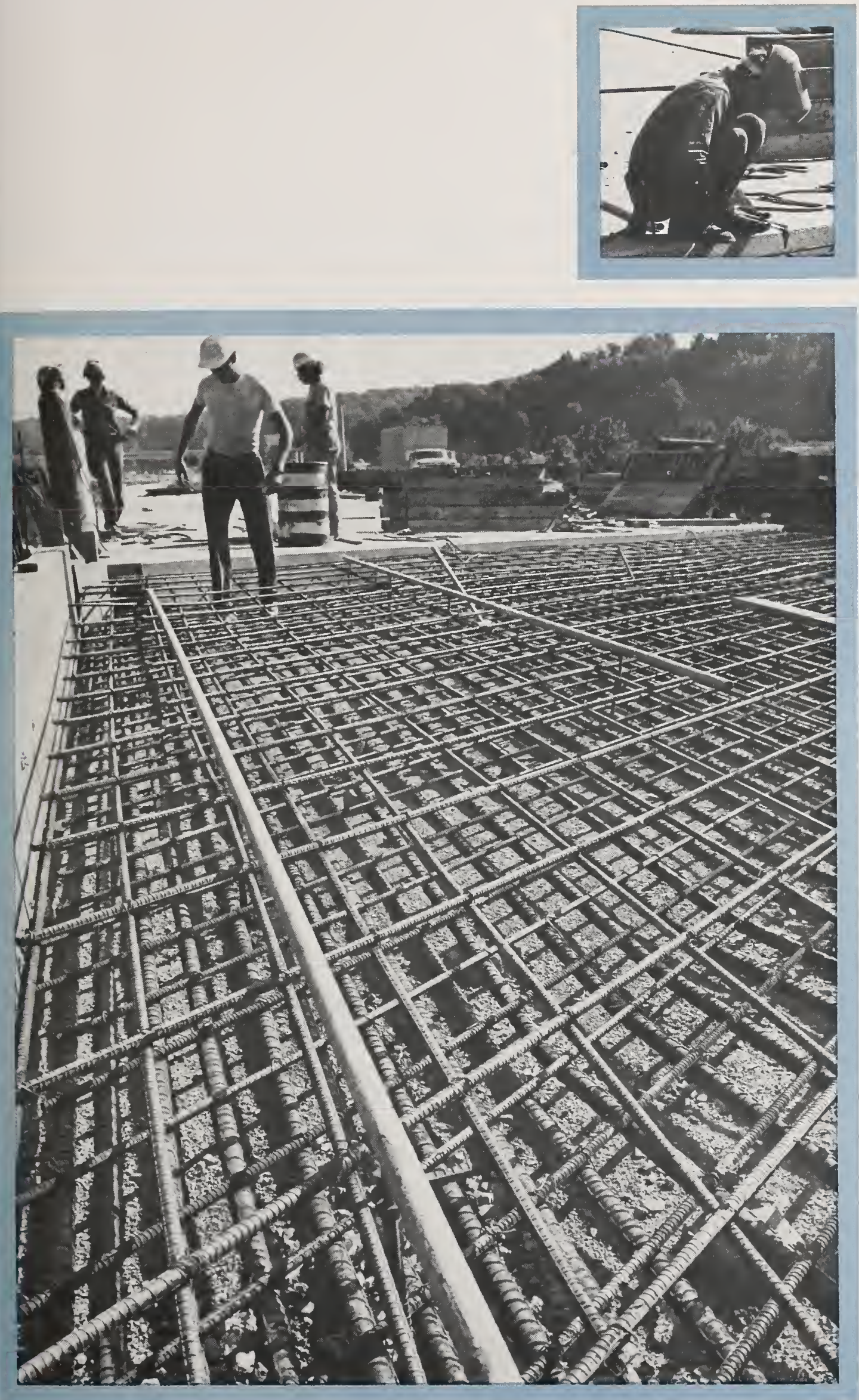

guide to surgeons in

planning their patients

therapy. In other work, NBS

researchers developed a new device to measure the wearresistance of dental restorative materials or fillings. The apparatus, which simulates conditions in the mouth, replaces a clinical test and reduces the time required to measure durability from years to days. By determining how materials fail, researchers can learn how to prevent failures. For the Bureau of Aviation Safety and the Naval Air Test Center, NBS analyzed a failed piston rod and rod end from a DC-8 landing gear. The Federal Railroad Administration relied on NBS expertise for metallurgical and chemical analyses of fragments recovered from tank car accidents. Bureau staffers also went to White Sands New Mexico, for a field test of an insulated rail tank car. Later, NBS performed detailed studies of 45 metal specimens taken from the car. When a bridge collapsed over North Carolina's Yadkin River, the Bureau examined the bridge's fractured members for the National Transportation Safety Board. In each instance, the sponsors now have NBS test data to help in determining how to reduce the probability of similar accidents recurring. 


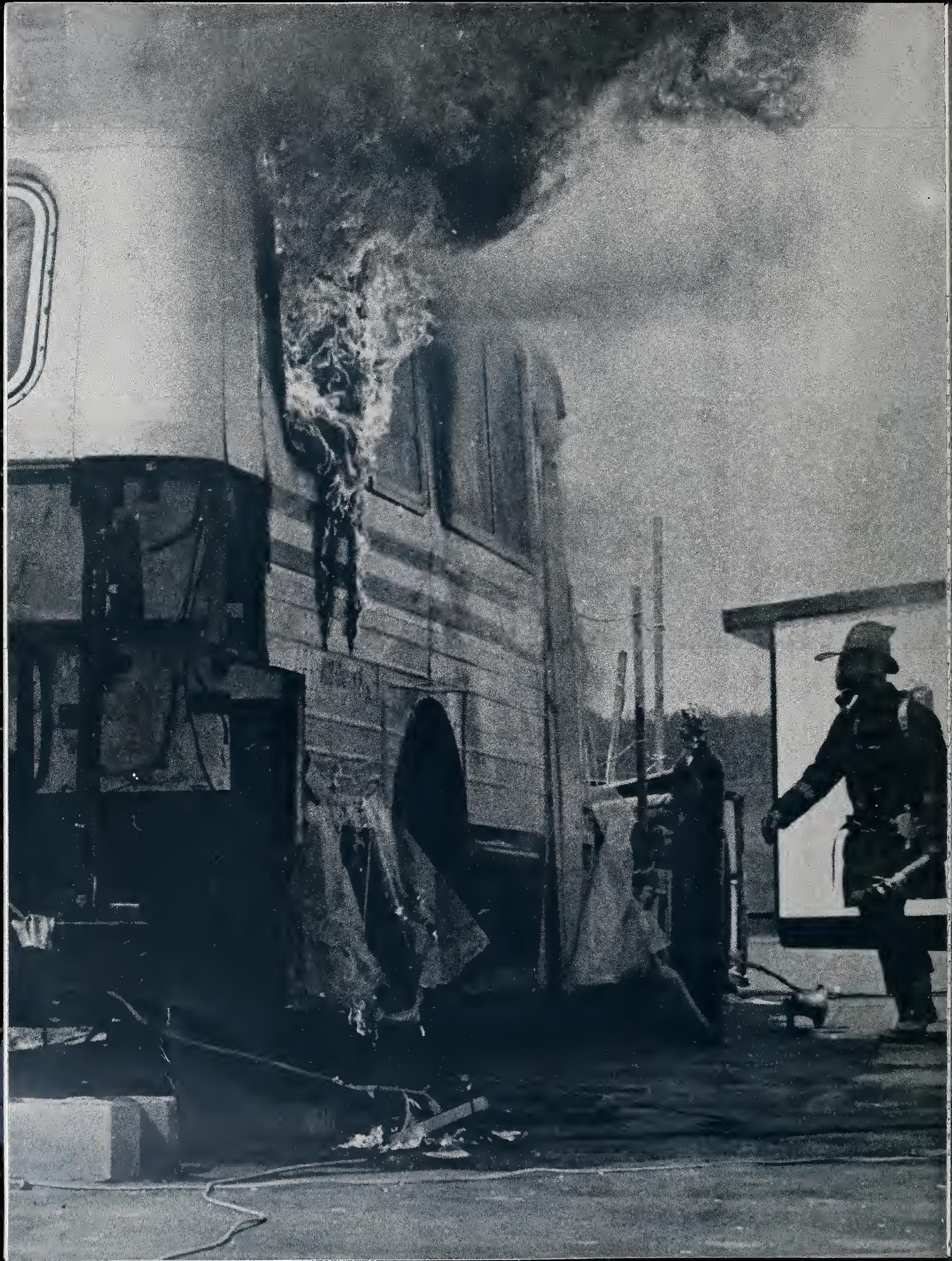




\section{Improving \\ Product \\ Safety}

$\mathrm{T}$ HE marketplace is filled with products of every description. Some, like recreational products, are luxuries. Other products are essential to specialized consumers, such as retail storeowners. Still other "products," like our homes, are huge investments to protect. During FY75, NBS investigated ways to aid consumers through better use of measurement science and technology for improved products.

To consolidate its product-oriented programs, the Bureau formed the Center for Consumer Product Technology. This umbrella organization manages about 50 NBS projects for the Consumer Product Safety Commission (CPSC). The Center also directs all NBS work for the Justice Department's National Institute for Law Enforcement and Criminal Justice.

The safety of recreational products is one Center concern. During the fiscal year, the Bureau developed a recommended voluntary product standard for home playground equipment used by children between the ages of 2 and 10 . The standard covers items ranging from paint toxicity to materials strength requirements.

Like other voluntary product standards processed by the Bureau, the playground standard is a consensus standard containing guidelines that industry has agreed to accept. Though not mandatory, voluntary product standards influence the marketplace through their emphasis on better and safer product performance and simplified practices.

In addition, FY75 saw the completion of an indepth study of stairways, ramps, and landings. NBS safety researchers studied videotapes of people using stairways to learn how falls happen. Distraction emerged as the biggest cause of falls. Armed with this information, NBS researchers are drawing up proposed performance criteria and design guides aimed at reducing the estimated 356,000 stairway accidents each year.

Modern technology has put many new products at the disposal of law enforcement and criminal justice agencies. More and more, police officers depend on high-technology equipment. By providing technical guidance to law enforcement authorities in evaluating and selecting equipment, the Bureau contributed to better police protection in FY75.

Reducing crime is a major law enforcement goal. Shoplifters-who are responsible for an annual $\$ 3$ billion "business" — can be discouraged by surveillance cameras. With the Selection and Application Guide to Fixed Surveillance Cameras, prepared by NBS in cooperation with the Naval Surface Weapons Center, owners of retail stores can decide whether to buy cameras and how to use them for the best results. Several equipment standards were also issued in FY75. Some of these cover the police officer's "everyday" equipment, such as fixed and base station FM transmitters, metallic handcuffs, and crash helmets. Others deal with non-routine items like handheld metal detectors and portable X-ray devices for bomb squads. An NBSdeveloped Standard Reference Material for the type of glass found in automobile headlights will aid forensic laboratories in examining glass fragments from hit-and-run cases and other crimes involving cars.

Certain law enforcement equipment standards gained widespread acceptance during the year. The Federal Bureau of Investigation, for example, recommended using NBS-developed standards for handcuffs in police procurement and the National Park Service's Protection Division began purchasing handcuffs conforming to the standard. Meanwhile, the Federal Housing Administration (FHA) made plans to require application of NBSdeveloped door security standards in all FHA-insured homes.

Another aspect of home security is protection against the threat of fire. With the Federal Fire Prevention and Control Act of 1974,
Left. In FY75, NBS conducted a series of full-scale fire tests on a Washington Metropolitan Area Transit Authority bus. 
Distraction was found to be a major cause of accidents on stairways according to a recent NBS report.

NBS is in the process of studying many recreational products for safety. In FY75, the Bureau formulated a voluntary product standard for home playground equipment.

NBS is currently in the process of developing recommendations on the most effective placement of smoke detectors for homeowners.
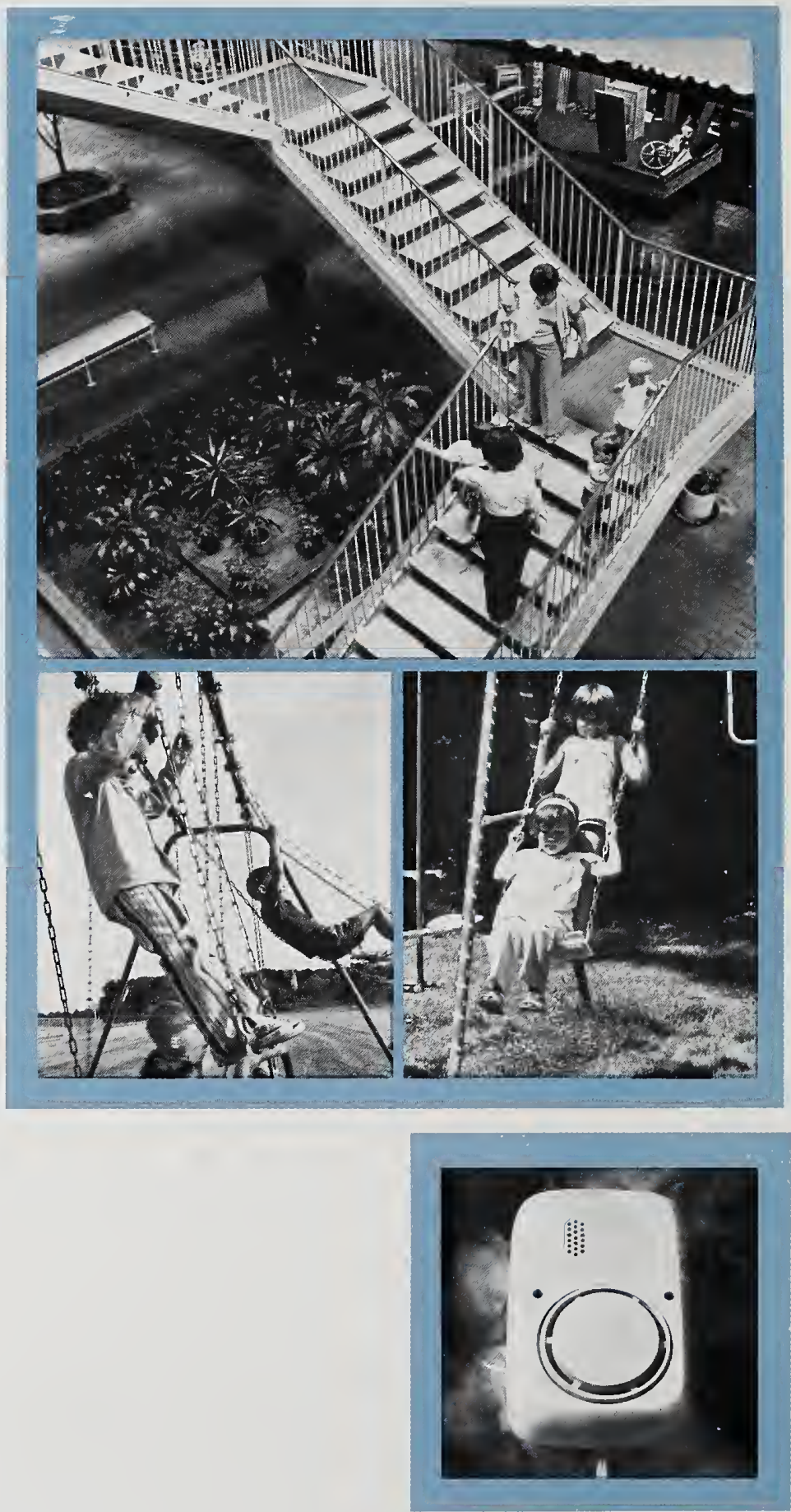

Congress strengthened the Bureau's 70-year-old tire program by establishing a Center for Fire Research at NBS. A nationwide fire survey, cosponsored by the Center and the Consumer Product Safety Commission in FY75, revealed just how serious the threat of fire is: an estimated 5,575,000 fires, costing $\$ 1.5$ billion in property damage, in American homes yearly. The landmark survey gives, for the first time, a statistically accurate assessment of the fire problem in American households.

Combustion products-smoke and toxic gasesaccount for as much as 90 percent of all fire fatalities. To reduce this toll, the Bureau funded three major investigations of combustion products, including a detailed study of the causes of death in fire victims, particularly deaths from smoke inhalation. An NBS study on smoke detector placement in the home is now underway and will help homeowners protect themselves and their homes. The Bureau also responded to an urgent firesafety request from the Washington Metropolitan Area Transit Authority (WMATA) during FY75. A series of suspicious bus fires prompted WMATA to turn to NBS for fire testing. The Bureau conducted a series of small-scale tests on bus carpeting and seats and large-scale tests of an entire bus. The tests pinpointed urethane padding in bus seats as potentially hazardous when ignited. 


\section{Providing Information as a Resource}

TNORMATION is one of 1 the Bureau's most important products. Through its varied information services, NBS shares its research results with many audiences. NBS receives-and answers-thousands of information requests from the public yearly. In FY75, the NBS information and inquiries staff received 63,800 letters and 13,500 telephone calls asking about everything from dead-weight gage calibration to the safety of wooden fire escapes. More than 50,000 of these letters asked about the metric system.

Since more than 1,000 people a month request a specific NBS publication, some information requests can be answered by simply sending that NBS

publication. The Bureau has 15 publications series, ranging from the Consumer Information Series to the Journals of Research and technical monographs. Last year, NBS published more than 45,000 pages of research results in the open

literature-an increase of 52 percent over FY74.

With its Standards Information Service, established in 1965, the Bureau provides a standards information clearinghouse. During the fiscal year, the Bureau added 8,200 standards to its data base bringing the total to over 200,000 standards published by more than 500 domestic, foreign, and international standards organizations. The Bureau shares this information resource with scientists, representatives of industry, and the public.

The Bureau also maintains the National Standard Reference Data System (NSRDS), a nationwide program designed to give scientists and engineers access to reliable data. NSRDS was established by Congress in 1968 and now has a network of 21 data evaluation and analysis centers across the country. In FY75, NBS and its collaborators conducted over 40 projects to compile critically evaluated data in several areas, including nuclear properties and chemical kinetics of various elements. The data are disseminated through such publications as The Journal of Physical and Chemical Reference Data, which is published in cooperation with the American Institute of Physics and the American Chemical Society and which completed its third year in FY75.

The Bureau offers additional insight into NBS activities and services through consumer publications, tours, and exhibits. Last year NBS sponsored or cosponsored 64 major conferences, which had a total of 11,769 participants. Eight new exhibits, including Think Metric and Treaty of the Meter, were built in FY75. NBS exhibits were displayed at a total of 50 places where they were viewed by over 275,000 people.

Thirty-four tours were given to 327 VIP's, such as members of Congress, business leaders, and

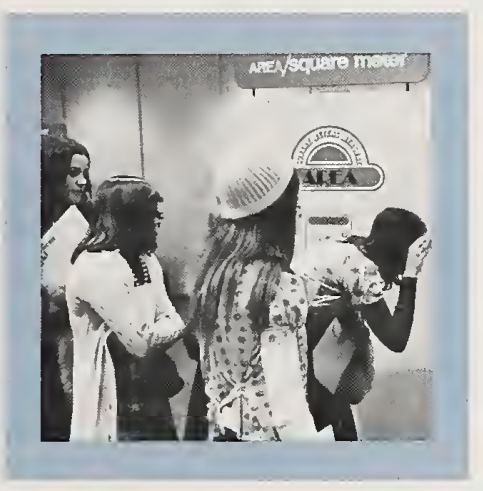

representatives of other national standards laboratories. A total of 4,736 people saw NBS in FY75 through special and regularly scheduled tours.

Anyone wishing more detailed information on Bureau activities is encouraged to contact the Office of Information Activities, National Bureau of Standards, Washington, D.C. 20234.
This audience participation exhibit allows viewers to experience metric measurements. It is being displayed in museums across the country.

NBS' National Standard Reference Data System seeks to reduce data pollution by recommending good data and by compacting the total volume of data to be searched.

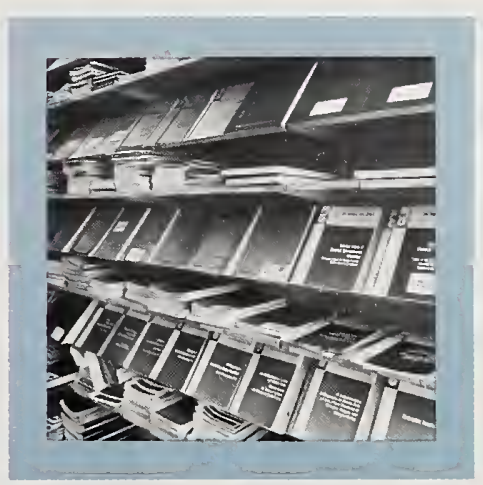




\section{Organization}

THE NBS staff is organized into four major institutes:

$\square$ The Institute for

Basic Standards (IBS)

provides the central base

within the United States for a complete and consistent system of physical measurements and coordinates that system with measurement systems of other nations. It furnishes the research and essential services leading to accurate and uniform physical measurements and reliable data throughout the Nation's scientific, industrial, and commercial communities. IBS also operates the Boulder Laboratories and cosponsors the Joint Institute for Laboratory Astrophysics with the University of Colorado.

$\square$ The Institute for

Materials Research (IMR) conducts research to provide a better understanding of the basic properties of matter and materials and develops standards for measuring their properties to help insure their proper utilization by the Nation's scientific, industrial, and commercial communities. IMR also develops, produces, and distributes Standard Reference Materials which provide the basis for calibration of instruments and equipment, comparison of measurements on materials, and aid in the control of production processes in industry.

$\square$ The Institute for Applied Technology (IAT) is concerned with developing technology and applying it to such areas as building research, fire research and safety, consumer product performance and safety, and electronics. IAT represents the public interest in the development of voluntary engineering standards and develops standards, tests, and services to protect the public from hazardous products.

$\square$ The Institute for Computer Sciences and Technology (ICST) is the scientific and technical arm of the Federal government's automatic data processing management system. In this role, ICST provides advisory services to Federal agencies to support the formulation of automatic data processing management and procurement policies and to assist individual agencies in solving specific automation problems. ICST also develops Federal Information Processing Standards and conducts research in computer science and technology.

The institutes are supported by the Office of the Associate Director for Administration; the Office of the Associate Director for Programs, which performs policy development and program analysis and planning; and the Office of the Associate Director for Information Programs, which focuses the flow of information into and out of NBS and which manages the National Standard Reference Data System.

This amalgam of people and programs forms a community dedicated to service. The interdisciplinary approach allows NBS to provide the Nation with scientific measurements of high precision and accuracy, coupled with actual solutions for current technological problems. 


\section{U.S. Department of Commerce \\ National Bureau of Standards}

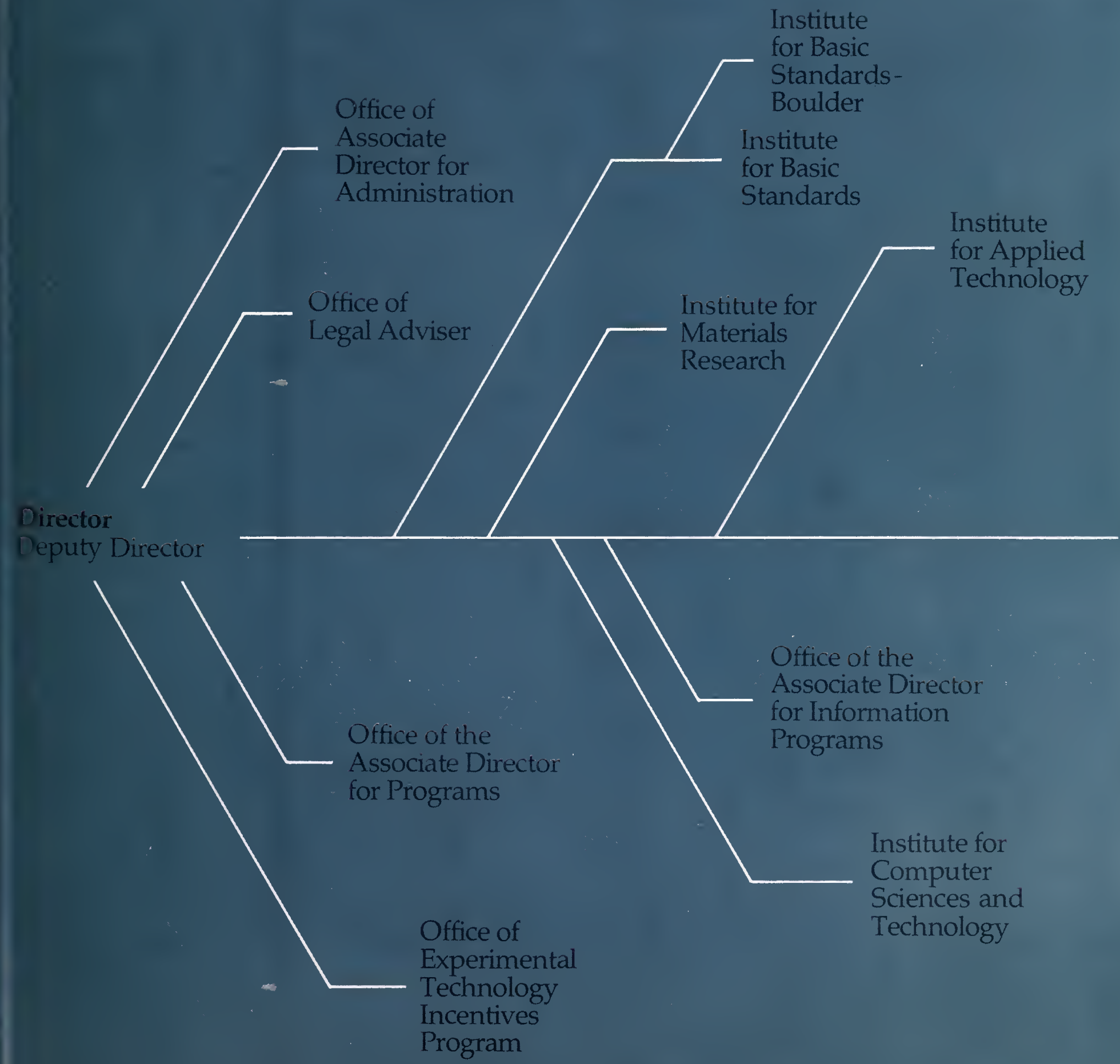




\section{Funds and Facilities}

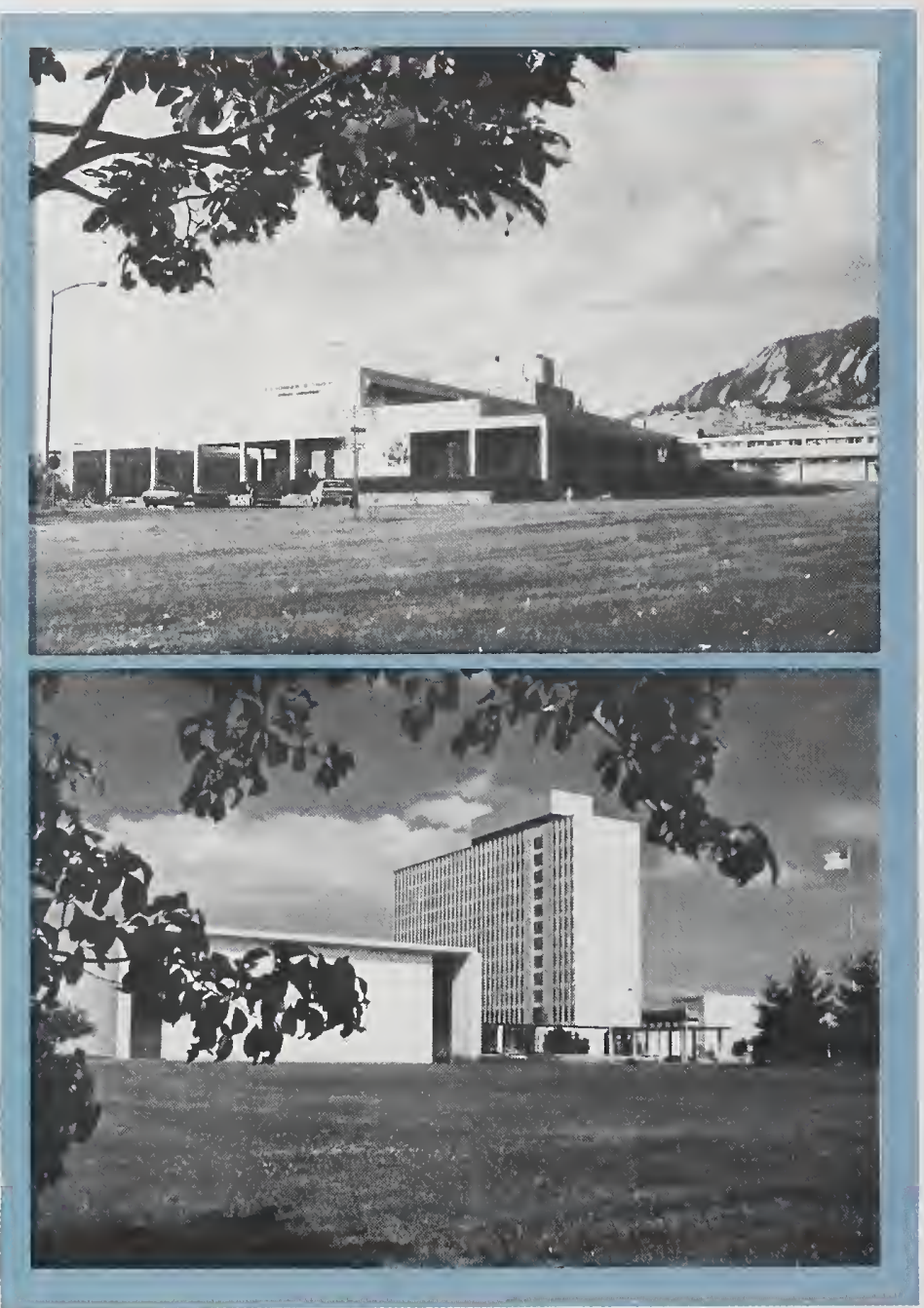

Top. NBS Boulder laboratories.

Bottom. NBS Gaithersburg laboratories.
$\mathrm{T}_{\mathrm{O}}^{\mathrm{O}}$

O support its many activities, the Bureau received $\$ 107$ rillion in FY75. Direct Congressional appropriations accounted for approximately 55 percent of NBS funds, with an additional 39 percent resulting from work performed by the Bureau for other government agencies. The sale of NBS goods and services, such as calibrations and Standard Reference Materials, provided the final 6 percent. The increase in funding from other agencies in recent years reflects the Bureau's emerging role as a major physical sciences research organization for the entire Federal government. To carry out its sophisticated research and services, the Bureau operates a modern physical plant. NBS has two main locations: Gaithersburg, Maryland (north of Washington, D.C.) and Boulder, Colorado. The Gaithersburg site has 27 buildings, scattered in a campus-like setting on 233 hectares ( 1 hectare equals 2.5 acres). The Bureau has 14 buildings on 83 hectares in Boulder. Also in Boulder is the University of Colorado, where NBS studies atomic and molecular physics at the Joint Institute for Laboratory Astrophysics.

In a Ft. Collins

Colorado, field station, NBS radio stations WWV and WWVB broadcast standard time and frequency information. Another station, WWVH, broadcasts from Kauai, Hawaii. In Clearing, Illinois, the Bureau has a facility with a railway master track scale and two test cars that are used to calibrate master track scales owned by railways around the country.

The Bureau uses a wide variety of unique equipment at its facilities. Included in NBS' inventory are a high flux nuclear reactor, a reverberating chamber, and a mechanical testing machine for applying and measuring tension and compression loads-one of the world's largest. A cryogenic flow research facility provides a continuous flow of liquid nitrogen and the ability to control flow rate, temperature, and pressure over wide ranges.

An extensive instrument shops division answers specialized research needs. Shop capabilities include glassblowing, optics, and metalworking. The Bureau's equipment is described more fully in Special Technical Facilities at the National Bureau of Standards, NBS Special Publication 413. This 50-page booklet is available from the Superintendent of

Documents, U.S.

Government Printing Office, Washington, D.C. 20402 , and may be ordered by SD Catalog No. C13.11:413 for $\$ 1.10$. 


\begin{tabular}{|c|c|c|c|}
\hline & $\begin{array}{c}\text { Fiscal } \\
7974\end{array}$ & $\begin{array}{l}\text { Fiscal } \\
1975\end{array}$ & $\begin{array}{l}\text { Fiscal } \\
1976 \\
\text { (est.) }\end{array}$ \\
\hline $\begin{array}{l}\text { Provide a national system for } \\
\text { physical measurement }\end{array}$ & 32.0 & 34.4 & 34.8 \\
\hline $\begin{array}{l}\text { Physical measurements, units, } \\
\text { and standards }\end{array}$ & 22.3 & 24.2 & 24.5 \\
\hline $\begin{array}{l}\text { Reference measurements for } \\
\text { physical quantities }\end{array}$ & 9.7 & 10.2 & 10.3 \\
\hline $\begin{array}{l}\text { Provide services to improve use } \\
\text { of materials }\end{array}$ & 22.0 & 25.5 & 25.8 \\
\hline $\begin{array}{l}\text { Properties and performance of } \\
\text { materials }\end{array}$ & 16.1 & 20.0 & 20.2 \\
\hline Reference materials & 2.1 & 2.1 & 2.1 \\
\hline $\begin{array}{l}\text { Environmental pollution meas- } \\
\text { urements }\end{array}$ & 3.8 & 3.4 & 3.5 \\
\hline $\begin{array}{l}\text { Provide services to improve the } \\
\text { application of technology }\end{array}$ & 27.8 & 31.3 & 33.4 \\
\hline $\begin{array}{l}\text { State weights and measures } \\
\text { services }\end{array}$ & .6 & .6 & .6 \\
\hline $\begin{array}{l}\text { Voluntary engineering stand- } \\
\text { ards }\end{array}$ & 1.7 & 1.9 & 2.0 \\
\hline $\begin{array}{l}\text { Building science and technol- } \\
\text { ogy }\end{array}$ & 8.9 & 11.3 & 11.5 \\
\hline Electronic technology & 3.3 & 3.5 & 3.7 \\
\hline Cryogenic technology & 1.8 & 1.5 & 1.5 \\
\hline Product performance and safety & 5.8 & 5.5 & 7.1 \\
\hline Radiation safety & .8 & 1.2 & 1.2 \\
\hline Fire research & 4.9 & 5.8 & 5.8 \\
\hline $\begin{array}{l}\text { Improve the application of } \\
\text { computer technology }\end{array}$ & 9.8 & 9.9 & 8.0 \\
\hline $\begin{array}{l}\text { Support services to other agen- } \\
\text { cies }\end{array}$ & 2.5 & 2.9 & 2.9 \\
\hline $\begin{array}{l}\text { Experimental Technology In- } \\
\text { centives Program }\end{array}$ & 6.1 & 3.0 & 4.4 \\
\hline TOTAL & 100.2 & 107.0 & 109.3 \\
\hline
\end{tabular}




\section{People}

UIDED by the NBS

IExecutive Board, the Visiting Committee, and a system of Evaluation Panels, the Bureau staff works to increase measurement competence and share its scientific and technical expertise with the scientific community, industry, and the public.

The staff has grown from its original 11 in 1901 to about 3,100 full-time employees. Approximately 2,600 are located in Gaithersburg, Maryland, with the remainder in Boulder, Colorado. More than 1,000 Bureau staff members are physical scientists and engineers and more than 40 percent of the professional staff have earned doctorates. The professional staff, the largest percentage of the NBS staff, is supported by administrative, clerical, housekeeping, and groundskeeping personnel. The staff includes almost 400 technicians.

NBS provides advanced training for representatives of science and industry. For example, in FY75 22 scientists who had recently earned doctorates in physical sciences and engineering began 1-year post-doctoral research associateships at the Bureau. They undertook advanced research projects guided by senior NBS scientists in the 20-year-old program administered by the National Research Council.

In addition, NBS hosted

88 industrial research associates in FY75. The Bureau's first six industrial research associates were appointed in 1921. Since then, more than 1,000 research associates have worked at NBS. Under the sponsorship of individual companies and trade and professional societies, the research associates work fulltime at the Bureau on projects of concern to both the sponsor and NBS.

During the fiscal year, more than 30 programs, including eight new projects, were underway. Eight program extensions were negotiated during the year.

The NBS Executive

Board oversees the efforts of the entire Bureau staff. For advice, the Executive Board turns to the NBS Visiting Committee, created by the Bureau's Organic Act. The Committee is concerned with all aspects of the Bureau, including the scientific wellbeing of programs and the condition of equipment and facilities. Yearly, the Committee reports its findings to the Secretary of Commerce.

The NBS Evaluation Panels are more involved with specific Bureau projects. Panel members review the activities of each technical division and institute. An Executive Committee of panel members reports the findings and recommendations of each panel to the NBS Director and the Visiting Committee. The National Academy of Sciences, the National Academy of Engineering, and the National Research Council appoint the approximately 200 members of NBS Evaluation Panels.

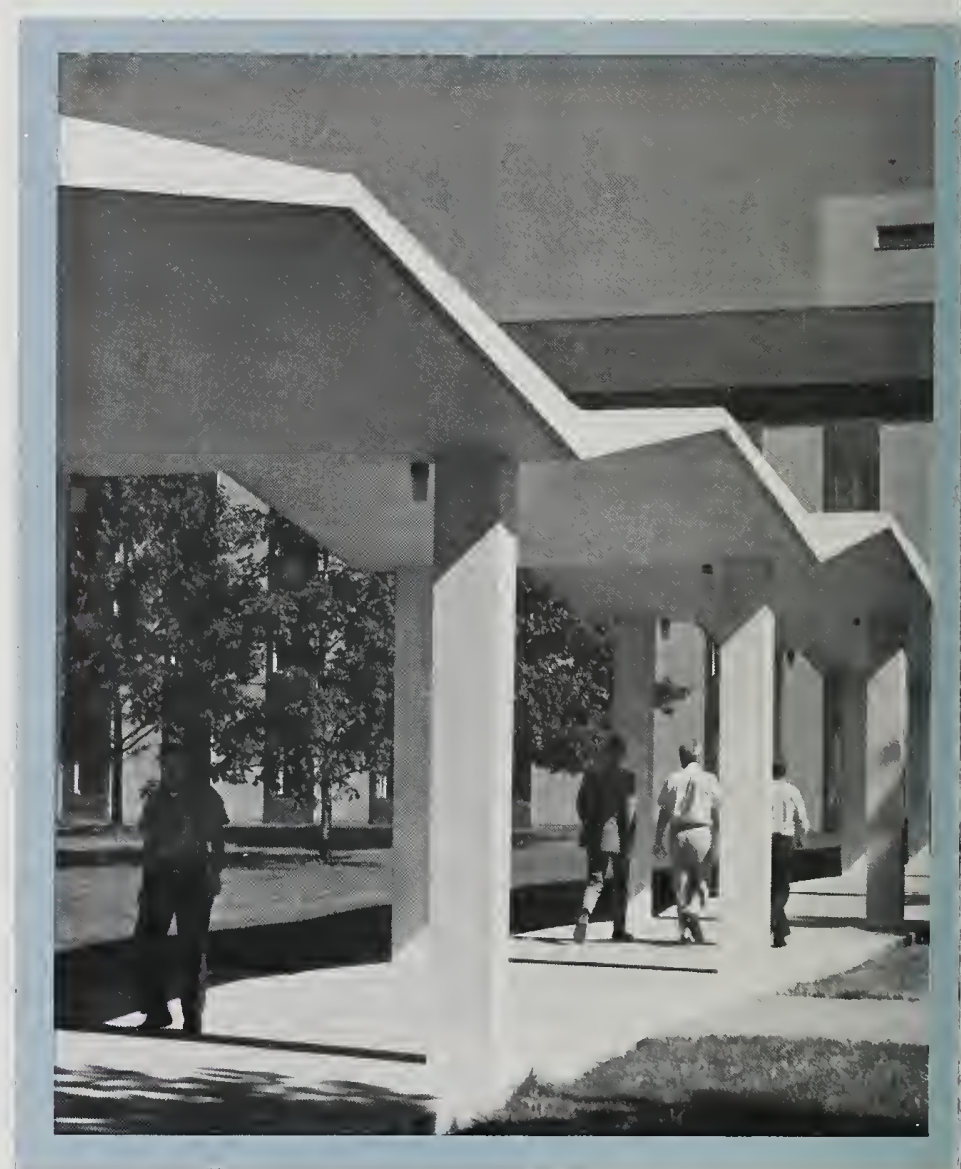


The contributions of NBS employees to the advancement of science and technology are often recognized by outside organizations. During the fiscal year, those staff members honored by independent and professional organizations included:

\section{JOHN R. AMBROSE of the} Corrosion and Electrodeposition Section received the Melvin Romanoff Award of the National Association of Corrosion Engineers (Northeast Region).

WILLIAM E. ANDRUS from the Office of Engineering and Information Processing

Standards was elected to a 6year term as vice president of the International

Organization of Legal

Metrology.

\section{LAWRENCE H. BENNETT}

received the American Society of Metals' Burgess Memorial Award for his research in the Alloy Physics Section.

HAROLD BERGER of the Reactor Radiation Division was awarded the American Nuclear Society's Radiation Industry Award for research and basic developments in neutron radiography. He was also named a Fellow of the Society.

DOUGLAS M. BURCH of the Center for Building Technology was granted the H.C. Carrier Award from the Carrier Corporation for experimental and analytical work on the NBS masonry blockhouse and townhouse.

LOUIS COSTRELL, chief of the Radiation

Instrumentation Section, received the Harry Diamond Award from the Institute of Electrical and Electronic Engineers for outstanding achievements in nuclear radiation measurement techniques.

ROBERT CRIST, chief of the Structures Section of the Center for Building

Technology, was one of 21 committee members awarded the 1974 State-ofthe-Art Civil Engineering Award from the American Society of Civil Engineers.
RUTH M. DAVIS, director of the Institute for Computer Sciences and Technology, was elected to membership in the National Academy of Public Administration.

ARTHUR M. DINESS, a guest worker in the Physical Properties Section, was named a Fellow of the American Ceramic Society.

ANTHONY EVANS and MELVIN LINZER, both of the Inorganic Materials Division, received the Ross Coffin Purdy Award from the American Ceramic Society for outstanding contributions to ceramic literature.

\section{GEOFFREY}

FROHNSDORFF, chief of the Materials and Composites Section of the Center for Building

Technology, received a Certificate of Merit from and designation as Fellow of the American Ceramic Society.

ARTHUR HOCKMAN of the Center for Building

Technology received an American Society for Testing and Materials Award of Merit and designation as

Fellow for contributions to standards development for sealants and caulking materials.

WARREN P. IVERSON won the Charles Thom Award from the Society of Industrial Microbiology for his work in the Corrosion and

Electrodeposition Section.

MADELEINE JACOBS of the Office of Information Activities was honored by the Federal Editors

Association for her technical news release on an NBSdeveloped chlorine monitor. ROBERT A. KAMPER of the Electromagnetics Division received the Arnold $O$. Beckman Award from the Instrument Society of America for contributions to the application of the Josephson effect to new measurement systems.
THEODORE LASHOF, chief of the Laboratory Performance Section, was granted an Award of Merit from the American Society for Testing and Materials for his leadership in establishing the precision of paper test methods.

H. L. MASON of the Office of Information Activities and IRIS M. LLOYD of the Management and

Organization Division were honored by the Washington D.C., chapter of the Society for Technical

Communications for editing Special Technical Facilities at the National Bureau of Standards.

FIELDING OGBURN was granted the Scientific Achievement Award of the American Electroplaters Society for his work in the Corrosion and

Electrodeposition Section.

RICHARD W. ROBERTS

former Director, received the Arthur S. Flemming Award from the Downtown Jaycees of the District of Columbia for his effective

administration of the Bureau.

ROY G. SALTMAN of the

Information Technology Division was granted an Intergovernmental Affairs Fellowship by the Civil Service Commission.

SAMUEL J. SCHNEIDER of the Solid State Chemistry Section was named a Fellow of the American Ceramic Society for his work in phase equilibria.

BARRY N. TAYLOR, chief of the Electricity Division, received the John Price Wetherill Award from the Franklin Institute for work with the a.c. Josephson junction.

JACK TECH of the Optical Physics Division received an Honor Award for Superior

Performance from the Department of State for distinguished and

exceptional service in advancing U.S.-Sovie cooperation in science and technology.
F. KARL WILLENBROCK director of the Institute for Applied Technology, was elected to membership in the National Academy of Engineering.

JAMES R. WRIGHT, deputy director of the Institute for Applied Technology, was elected to the Bureau (Board of Directors) of the

International Union of Testing and Research Laboratories for Materials and Structures (RILEM).

HARVEY YAKOWITZ, DALE NEWBURY, and ROBERT MYKLEBUST, all of the Metallurgy Division, were granted the Corning Award from the Microbeam Analysis Society.

\section{NBS Executive Board}

Dr. Richard W. Roberts* Director

Dr. Ernest Ambler Deputy Director

Dr. Arthur O. McCoubrey Director, Institute for Basic Standards

Dr. John D. Hoffman

Director, Institute for Materials Research

Dr. F. Karl Willenbrock Director, Institute for Applied Technology

Dr. Ruth M. Davis

Director, Institute for Computer Sciences and Technology

Dr. Howard E. Sorrows Associate Director for Programs

Paul H. Schrader

Acting Associate Director for Administration

Dr. Edward L. Brady

Associate Director for

Information Programs

NBS Visiting Committee

Dr. Arthur Bueche, Chairman Vice President for Research and Developnent General Electric Company

Dr. Robert Dicke

Professor of Physics

Princeton University

Dr. Edwin Gee

Senior Vice President

E. I. du Pont de Nemours

*RESIGNED IUNE 30, 1975

Charles Peck

Vice President

Owens-Corning Fiberglas

Dr. John Truxal

Dean of the College of

Engineering

State University of New York at Stony Brook

Evaluation PaneI

Executive Committee

Dr. W. O. Baker, Chairman

President

Bell Laboratories

Dr. Jordan Baruch (Chairman, Institute for Computer Sciences and Technology Panel

Amos Tuck Graduate School of Business Administration Dartmouth College

Professor Raymond A. Bauer (Chairnian, Institute for Applied Technology Panel) Harvard Business School

Dr. Harry C. Gatos

(Chairman, Office of Standard Reference Data Panel)

Department of Metallurgy and

Materials Science

Massachusetts Institute of Technology

Dr. Milton Harris (Chairman, Experinental Technology Incentives Program Panel) 
Michael Witunski (Memberat-Large)

McDonnell Douglas

Corporation

Evaluation Panel-Institute for Basic Standards

Dr. Roland W. Schmitt,

Chairman

Research and Development

Manager

Physical Science and

Engineering

General Electric Research and

Development Center

Dr. C. A. Bennett (Chairman, Applied Mathematics Division Panel)

Staff Scientist

Battelle

Human Affairs Research

Centers

Dr. Herbert P. Broida (Chairman, Optical Physics Division Panel)

Department of Physics University of California at Santa Barbara

Professor James W. Daily (Chairman, Mechanics Division Panel)

Department of Applied

Mechanics and Engineering

Science

University of Michigan

Professor Vernon J. Ehlers

(Member-at-Large)

Department of Physics

Calvin College

R. W. Flugum (Chairman Electricity Division Panel)

Director-Applied Research

The Ohio Brass Company

Professor Ronald Geballe (Chairman, Laboratory

Astrophysics Division Panel)

Associate Dean, College of Arts and Sciences

University of Washington

Dr. Charles M. Huggins

(Chairman, Time and Frequency

Division Panel)

Corporate Research and

Development

General Electric Company

Professor Donald N.

Langenberg (Chairman,

Cryogenics Division Panel)

Department of Physics

University of Pennsylvania

Dr. Darrell W. Osborne

(Chairman, Heat Division

Panel)

Senior Chemist

Argonne National Laboratory
Robert A. Soderman Chairman, Electromagnetics

ivision Panel)

General Radio Company

Dr. Richard F. Taschek

(Chairman, Center for

Radiation Research Panel)

University of California

Los Alamos Scientific

Laboratory

Evaluation Panel-Institute for Materials Research

Charles J. Meechan

Chairman

Corporate Vice President

Research and Engineering

Rockwell International

Professor Neil Bartlett

(Member-at-Large)

Department of Chemistry

University of California at Berkeley

Professor Morris Cohen (Member-at-Large)

Department of Metallurgy and Materials Science

Massachusetts Institute of Technology

Dr. Warren E. Falconer

(Chairman, Physical Chemistry Division Panel,

Director, Physical Chemistry

Research Laboratory

Bell Laboratories

Dr. Herbert I. Fusfeld

(Member-at-Large)

Director of Research

Kennecott Copper Corporation

Dr. Robert I. Jaffee

(Chairman, Metallurgy

Division Panel)

Technical Manager, Materials,

Fossil Fuels, and Advanced

Systems

Electric Power Research

Institute

Dr. Frank E. Jamerson

(Chairman, Measures for Air

Quality Panel)

Head, Physics Departmen

General Motors Research

Laboratories

Dr. David W. McCall

(Chairman, Polymers Division

Panel)

Chemical Director

Bell Laboratories

Dr. George H. Morrison

(Chairman, Analytical

Chemistry Division Panel)

Department of Chemistry

Cornell University
Dr. R. J. Stokes (Chairman, Inorganic Materials Division Panel)

Manager, Materials Science

Department

Honeywell Corporate Research Center

Dr. Max L. Yeater (Chairman,

Reactor Radiation Division

Panel)

Professor and Curriculum

Chairman, Nuclear Engineering

School of Engineering

Rensselaer Polytechnic Institute

Evaluation Panel-Institute for Applied Technology

Professor Raymond A.

Bauer, Chairman

Harvard Business School

William D. Carey (Member-atLarge)

Vice President

Arthur D. Little, Inc.

Professor Howard $W$.

Emmons (Chairman, Center

for Fire Research Panel

Harvard University

(deceased)

Dr. Hubert Heffner (Memberat-Large)

Professor, Applied Physics and

Electrical Engineering

Stanford University

Dr. David B. Hertz (Memberat-Large)

Director

McKinsey and Company, Inc.

Professor Percy Pierre

(Member-at-Large)

Dean of Engineering

Howard University

Henry Rowen (Chairman,

Technical Analysis Division

Panel)

School of Business

Administration

Stanford University

Dr. Gordon K. Teal

(Chairman, Electroni

Technology Division Panel)

retired, Texas Instruments Inc.

Dr. G. King Walters

(Member-at-Large)

Department of Physics

Rice University

Paul Weidlinger (Chairman,

Center for Building Technology

Panel)

Weidlinger Associates,

Consulting Engineers
Foster C. Wilson (Chairman, Center for Consumer Product Technology Panel)

Group Manager

Owens-Corning Fiberglas

Corporation

Dr. Eric Wolman (Member-at Large)

Head, Network Engineering

Department

Bell Laboratories

Evaluation Panel-Institute for Computer Sciences and Technology

Dr. Jordan Baruch, Chairman Amos Tuck Graduate School of Business Administration Dartmouth College

Bruno Augenstein

SpectraVision, Inc.

Dr. Julian Bigelow Institute for Advanced Study

Dr. William E. Bradley

President

Puredesal

Walter M. Carlson

Advanced Market Development

Consultant

IBM Corporation

Dr. Lawrence Goldmuntz

Economics and Science Planning

Dr. Robert R. Johnson

Vice President, Engineering

Burroughs Corporation

Lester Kilpatrick

President

California Computer Products

Inc.

William May

President and Chairman of the Board

American Can Company

Professor Alan K. McAdams

Graduate School of Business and

Public Administration

Cornell University

William Norris

President and Chairman of the

Board

Control Data Corporation

Alfred R. Zipf

Executive Vice President

Bank of America

Evaluation Panel-Office of Experimental Technology Incentives Program

Dr. Milton Harris,

Chairman

Consultant

Dr. Jordan Baruch

Amos Tuck Graduate School of

Business Administration

Dartmouth College

Dr. Herbert Fusfeld

Director of Research

Kennecott Copper Corporation

Dr. Neil V. Hakala

President

Exxon Research and

Engineering

Professor Walter R. Hibbard

Jr.

College of Engineering

Virginia Polytechnic Institute

Professor Edwin Mansfield

Department of Economics

University of Pennsylvania

Dr. Richard R. Nelson

Professor of Economics

Yale University

Dr. Charles. E. Reed

Senior Vice President

General Electric Company

Dr. Eli Shapiro

Chairman, Finance Committee

Travelers Insurance

Evaluation Panel-Office of Standard Reference Data

Dr. Harry C. Gatos,

Chairman

Department of Metallurgy and

Materials Science

Massachusetts Institute of Technology

Dr. A. Arnold Bondi Consulting Research Engineer Shell Development Company

Dr. Warren E. Falconer

Director, Physical Chemistry

Research Laboratory

Bell Laboratories

Dr. William H. Flygare

Noyes Chemical Laboratory 


\section{Credits}

Writer: Pamela A. Powell

Editor: Sharon A. Washburn

Photographers:

(Gaithersburg) H. Mark

Helfer with assistance from

Bessmarie Young and

Lawrence N. Hale

(Boulder) Harry D. Covey 


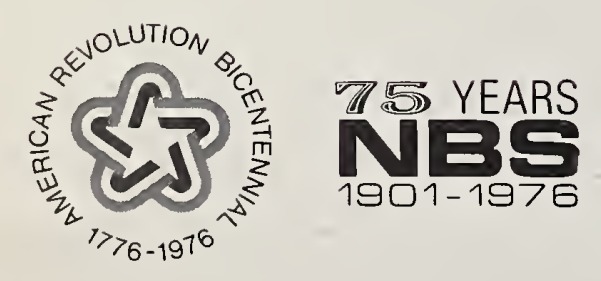

